Florida International University FIU Digital Commons

FIU Electronic Theses and Dissertations

University Graduate School

4-17-2014

\title{
Without an empire: Muslim mobilization after the caliphate
}

erik tisthammer

Florida International University, etist001@fiu.edu

DOI: $10.25148 /$ etd.FI14071161

Follow this and additional works at: https://digitalcommons.fiu.edu/etd

\section{Recommended Citation}

tisthammer, erik, "Without an empire: Muslim mobilization after the caliphate" (2014). FIU Electronic Theses and Dissertations. 1532. https://digitalcommons.fiu.edu/etd/1532

This work is brought to you for free and open access by the University Graduate School at FIU Digital Commons. It has been accepted for inclusion in FIU Electronic Theses and Dissertations by an authorized administrator of FIU Digital Commons. For more information, please contact dcc@fiu.edu. 


\title{
FLORIDA INTERNATIONAL UNIVERSITY
}

\author{
Miami, Florida
}

WITHOUT AN EMPIRE: MUSLIM MOBILIZATION AFTER THE CALIPHATE

A thesis submitted in partial fulfillment of

the requirements for the degree of

MASTER OF ARTS

in

INTERNATIONAL RELATIONS

by

Erik Tisthammer

2014 
To: Interim Dean Michael R. Heithaus

College of Arts and Sciences

This thesis, written by Erik Tisthammer, and entitled Without an Empire: Muslim

Mobilization After the Caliphate, having been approved in respect to style and intellectual content, is referred to you for judgment.

We have read this thesis and recommend that it be approved.

Maria Logrono

\begin{tabular}{c}
\hline John F. Clark \\
\hline Iqbal Akhtar, Major Professor
\end{tabular}

Date of Defense: April 17, 2014

The thesis of Erik Tisthammer is approved.

$\begin{array}{r}\text { Michael R. Heithaus } \\ \text { Interim Dean, College of Arts and Sciences } \\ \hline \begin{array}{r}\text { Dean Lakshmi N. Reddi } \\ \text { University Graduate School }\end{array}\end{array}$

Florida International University, 2014 


\section{DEDICATION}

To God for giving me grace, strength and wisdom, my wife for unbelievable love and patience, and my daughter Emily, who fills my life with joy. 


\section{ACKNOWLEDGMENTS}

I would like to thank the support and guidance of my Major Professor, Dr. Iqbal Akhtar. We have had many meetings over the past year and each one has shaped this paper and refined my research. Several courses taught by Professor Mesbahi, along with periodic meetings broadened my understanding of Islam and contributed to this thesis. Likewise, warm gratitude goes out to Professor Lograno for serving as a committee member and providing constructive feedback. My dad has edited my papers since I was 13 so much love and gratitude for his help throughout my academic career. My mom has been a constant source of encouragement and support. I could not be here without my parents. To the students of FIU, especially Ramsey, and all of the professors and educators of this great university. I enjoyed stepping on campus every day and have been challenged and pushed ever since I received my acceptance letter a few days after my daughter was born. 


\author{
ABSTRACT OF THE THESIS \\ WITHOUT AN EMPIRE: MUSLIM MOBILIZATION AFTER THE CALIPHATE \\ by \\ Erik Tisthammer
}

Florida International University, 2014

Miami, Florida

Professor Iqbal Akhtar, Major Professor

The Caliphate was a fundamental part of Islamic society for nearly 1300 years. This paper seeks to uncover what effect the removal of this institution had on the mobilization of Muslims in several parts of the world; Turkey, Egypt, and British India. These countries had unique experiences with colonialism, secularism, nationalism, that in many ways conditioned the response of individuals to this momentous occasion. Each country's reaction had a profound impact on the future trajectory of civil society, and the role of Islam in the lives of its citizens. The conclusions of this paper challenge the monolithic depiction of Islam in the world, and reveal the origins of conflict that these three centers of Muslim power face today. Much of the religious narrative now commonplace in Muslim organizations derive from this pivotal event in world history. 


\section{TABLE OF CONTENTS}

CHAPTERS

PAGE

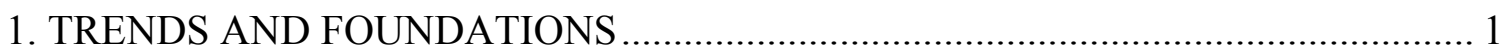

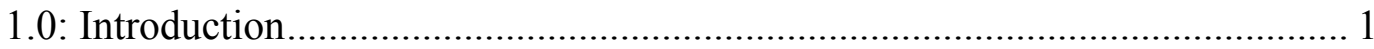

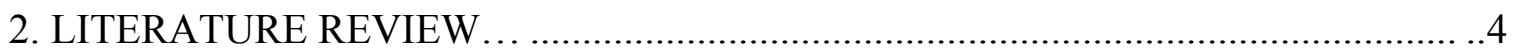

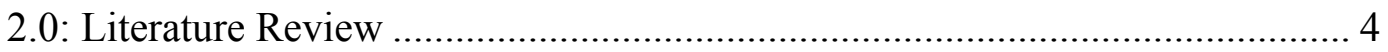

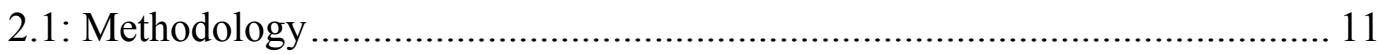

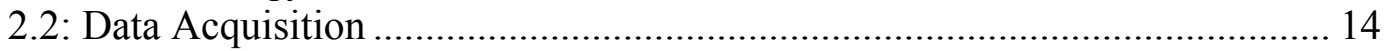

3. FALL OF AN EMPIRE RISE OF A NATION......................................16

3.0: The Fall of the Ottoman Empire............................................16

3.1: The Rise of Turkey ................................................ 21

3.2: Internal Opposition.................................................... 30

3.3: Religious Revolt.................................................. 34

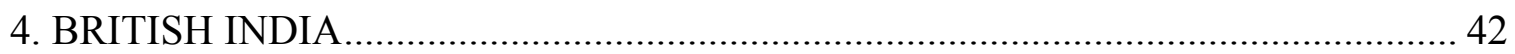

4.0: Role of the Caliphate in India ..................................................................... 42

4.1: The Occupation of Istanbul and the Indian Response ................................... 45

4.2: The Decline of the Khilafat Struggle ............................................................. 53

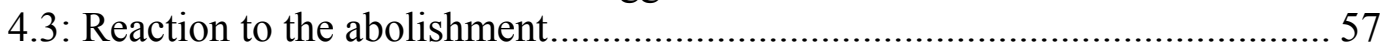

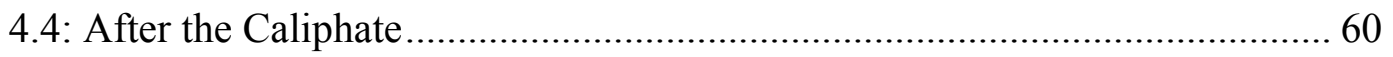

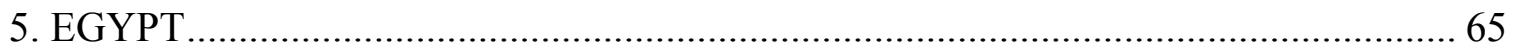

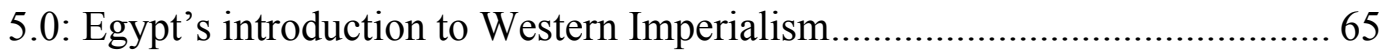

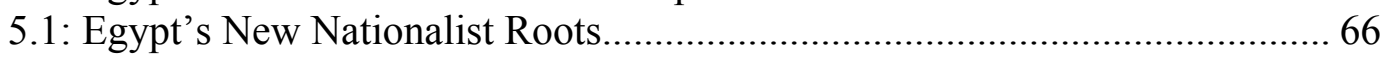

5.2: Removal of the caliphate and the conservative reaction....................69

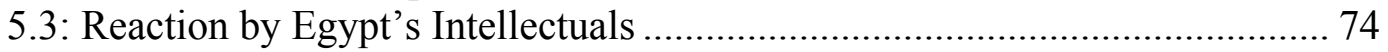

5.4: 1926 Cairo Caliphate Congress ………………........................................ 79

5.5: Formation of the Muslim Brotherhood .......................................................... 83

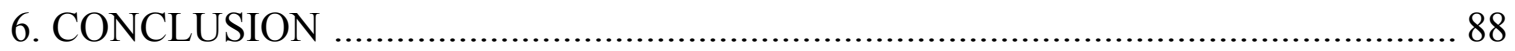

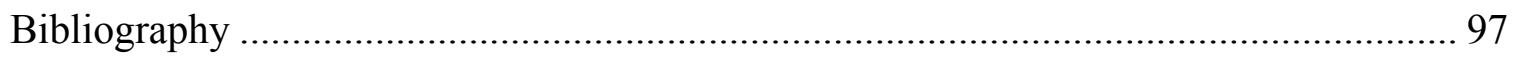




\section{CHAPTER 1}

\section{TRENDS AND FOUNDATIONS}

\section{0: Introduction}

The Ottoman Empire governed a wide range of territory from North Africa through the Middle East from 1299-1922. The Caliphate was an institution whose leader (Caliph), ruled over the Islamic state and held both political and religious power over its citizens. Gradually throughout the $19^{\text {th }}$ century, the institution of the Caliphate became separated from the political affairs of the Ottoman Empire and served more of a nominal role in the affairs of state. Its purpose largely became one of legitimizing the modernization programs of the Ottoman Empire so reforms would be more willingly accepted by the people. The Caliphate and the Ottoman Empire were the last of a long history of dynasties stretching back to the beginning of Islam that politically unified the Muslim community from North Africa to Southwest Asia.

After the Ottoman Empire was dissolved, a large portion of the Empire was partitioned among the British, French and Italian. The partition brought significant changes to regions that for centuries were accustomed to some type of religious hierarchy and authority that could arbitrate disputes, and more importantly, legislate according to Islamic law (sharia'). For the first time, as new national identities were formed, Muslims had to decide how to integrate their Islamic identity under colonial power. Questions emerged such as which laws were Islamic, and if whether it was possible to follow the secular law of the state and sharia' at the same time. 
My question is the following: After the dissolution of the Ottoman Empire and abolishment of the Caliphate, how and why did Muslims organize themselves and conceptualize Islam politically and socially without having an existing Islamic state for the first time in history? Why did some Muslim societies embrace western secular norms of governance and how did others attempt to reassert religious identity during a period of intense colonization?

These are relevant questions still being asked and debated among Muslims today. How does a religion which for nearly its entire existence called for and was dependent on a state to implement its decrees, survive and retain its essence in the midst of nations who follow secular jurisprudence? Muslims have had to wrestle with this question in every society, especially as the Muslim diaspora has grown in societies where religion continues to be marginalized and religious traditions clash with western concepts of social mores. Current examples can be seen in Europe where the Danish cartoon controversy of 2005 raised issues such as freedom of the press and sensitivity to the beliefs of others.

Furthermore, the concept of sharia' in society and restoring the Caliphate are two issues at the core of radical Islam. From central Asia to America's heartland (Oklahoma moved to ban sharia' in the state constitution), Islam's historical legal institutions and instruments are contested notions. They have been classified as irreconcilable with the modern world, God's mandate for mankind, or concepts that need to be redefined for the $21^{\text {st }}$ century. The debate concerning Islam's identity in the post-Caliphate world began 
when the Ottoman Empire faded away and the Caliphate that stood in place for hundreds of years in Istanbul ceased to exist.

Recent events in the Middle East illustrate the deep divisions between Muslims about the role of Islam in contemporary politics. The revolution in Egypt touches the very core of this issue with the rise and fall of the Muslim Brotherhood, an organization whose origin lies in the post-caliphate period of Egypt. Similarly, the dissolution of the Ottoman Empire and Caliphate was a watershed moment in Islam's history. This period served as a critical juncture where the conversation about Islam's role in society intersected with foreign powers, self-determination, and a nascent civil society that began to emerge as the Ottoman Empire crumbled. 


\section{CHAPTER 2}

\section{LITERATURE REVIEW}

\section{0: Literature Review}

My question is connected with literature pertaining to the concept of a 'crisis' in Islam. It would be incorrect to classify this as crisis theory, a term usually reserved for the Marxian critique of Capitalist economies who reach a point where they can no longer expand to new markets. Authors who invoke the word 'crisis' when speaking of Islam generally use it to explain the religion's perceived failure to incorporate certain aspects of modernity over the last several hundred years. Scholars attempt to qualitatively and quantitatively represent this through low human rights ratings for Muslim majority countries, human development index scores, and the inability of some countries to foster an industrious domestic economy capable of benefiting and contributing to the global economy.

Several themes emerge from scholars studying the notion of a crisis in Islam. One of these is the encounter between modernized European countries and their Muslim contemporaries in the Middle East and Asia (Lewis 2002). The term 'modernized' is not used to suggest a superior state of spiritual or moral progress, but the efficiency and capacity of technological innovation.

Lewis' thesis centers on the ability of Western countries to modernize their militaries, economies, and societies during the Renaissance and Industrial Revolution, and how this impacted provinces of the Ottoman Empire. The Ottomans began losing 
and surrendering territory on its periphery to Russian and European powers due to their inferior military technology. Politically, the Ottomans were unable to adapt and modernize their bureaucracy to meet rising costs and emerging challenges both from within and abroad. They also suffered from their inability or unwillingness to establish a robust printing industry in order to compete with ideas from abroad and circulate those within the Empire.

While Lewis' work is exhaustive, little discussion is devoted to the modern Middle East, rather he identifies how the Ottoman Empire crumbled in response to foreign and domestic pressures. He attempts to remedy this shortcoming in a later study by highlighting noteworthy events in the modern Middle East such as the assassination of Egyptian President Anwar Sadat and the Islamic revolution in Iran (Lewis 2003). Lewis eschews a comprehensive analysis of colonialism's long term implications and focuses instead on the modern genesis of Islamic terrorism. This shortcoming did not escape critique (Bulliet 2004), who argues that Islamic civilization survived colonialist domination and erected strong even if authoritarian state regimes. They diminished the role of the 'ulama, instituted mass education and fostered nationalist sympathies. Furthermore, some Muslims integrated seamlessly into western society as renowned doctors, professors, and entrepreneurs.

Ali Allawi, a former Minister of Trade and Defense for the Iraqi government, takes a comprehensive view of crisis in Islamic civilization (Allawi 2009). Allawi contends that part of Islam's decay has been the weakening of its vital forces and "the failure of Muslim rulers and societies to address the twin threats of growing European 
imperial power and the advent of modernity has exacerbated the Islamic crisis" (Allawi 2009: 26). This has led to differing models of governance and varying degrees of economic success and social stability. (Tibi 1988) reviews the history of Muslim, mostly Arab governments and describes three phases of social development in the Middle East. Tibi identifies the pressures on Islamic societies as colonization, westernization and modernity. These pressures have resulted in "an economic pauperization and a profound identity crisis requiring an ethnopsychological interpretation" (Tibi 1988: 46).

Another perspective believes that the crisis of Islam is a crisis of authority (Robinson 2009). Robinson focuses minutely on the emergence of print culture in the Ottoman Empire and the transmission of knowledge and recitation of the Quran. $\mathrm{He}$ argues this decoupled individuals from systems of institutions that held society together. Instead of Muslims learning in a communal environment, the advent of the printing press and pamphlets facilitated the diffusion of learning and modes of interpretation.

Bulliet (2002) contributes further to this theme by explaining that a "painful manifestation of a crisis of authority that has been building within Islam for a century". Bulliet notes that for the last century and a half the traditional religious authorities in Islam have been undermined by "new authorities" and had their power stripped by leaders in the Ottoman Empire and Egypt. He spends the rest of his analysis detailing recent movements within Muslim nations to re-establish control of the religious narrative.

Bulliet and Robinson provide a very cogent argument regarding the degradation of authority in Islam. However both structure their argument akin to Lewis, Allawi and Tibi; Islam's crisis stretches back several centuries and cannot be traced to a specific 
moment but constituted a gradual process in time. I have no disagreement regarding these points, but it is important to know, as some of these authors point out, what did Muslims aspire to after their Empire was officially non-existent? How Muslims in separate parts of the world conceptualized this crisis serves as another link in this chronological timeline Lewis, Allawi and Tibi present, but also aid in our understanding about how these trends have or have not continued in the present.

Thus, my study positions itself among scholars studying the concept of a crisis, but in a specific time, place and emphasis that others overlook, namely, the fall of the caliphate as a catalyst for sociopolitical and religious mobilization in the major Muslim centers of the world. A similar failure is prevalent in scholarly analysis concerning the abolishment of the caliphate. Most literature focuses on the long term ramifications of the event or the adoption of the institution as an organizational basis or narrative tool.

Arnold (1924) was perhaps the first to write about the effects of the caliphate's removal, though the work largely focuses on the origin and theory of the institution. Recent studies such as (Pankhurst 2013) analyze national and religious struggles in the midst of the caliphate's destruction, but focus more on transnational movements like Hizb ut- Tahrir, Al-Qaeda, and diaspora or sub-continent organizations. (Kersten and AlRasheed 2013) approach the abolition of the caliphate in a way similar to my hypothesis, with case studies on India and the effect on the Indonesian nationalist movement. However, these serve as outliers among twelve chapters of different contributors. Similar to Pankhurst, the emphasis is on the instrumental use of the caliphate in contemporary times and different contexts. 
One criticism regarding this idea of a 'crisis' in Islam is that it is a western, orientalist or colonialist constructed paradigm intended to aggrandize power or otherwise legitimize actions against Muslims in various parts of the world. In a review of Lewis' book "What Went Wrong", Joel Ariate, states that:

"[T]here is a danger in accepting the view that Islam suffers from certain 'weaknesses' as a religion, that it is in crisis...To accept these views is to realize that these discourses have successfully pathologized Muslim societies and politics, in particular those in the Middle East, that the stage for an outside intervention is set. A careful perusal of their respective books will show that though they have used different analytical optics...the implications of their arguments are unexpectedly the same: the West must change the Middle East" (Ariate 2003: 1-2).

Besides this being a gross misrepresentation of Lewis and the history of dissension within the Muslim community for the past two hundred years, two of the authors writing on crisis of Islam are Muslims. Additionally, contemporary Muslims and those who lived through the fall of the caliphate write about a crisis or decline of Islam. In the 1930's, intellectual Shakib Arslan wrote a short treatise titled "Our Decline: Its Causes and Remedies". ${ }^{1}$ Louay Safi, a Syrian born scholar of Islam, wrote in 2002 "Roots of the Intellectual's Crisis in the Arab Homeland". ${ }^{2}$

\footnotetext{
${ }^{1}$ Arslan, Shakib. Our Decline: Its Causes and Remedies. Kuala Lampur, Islamic Book Trust, 2004.

${ }^{2}$ Safi, L., and Ahmad Musilli. Judhur Azmat al-Muthaqaffi al-Watan al-'Arabi. Dar al-Fikr, Beirut, 2002.
} 
Furthermore, the scope of my argument and analysis is intended to focus on the words and actions of Muslims, not the normative practices of Western nations. I intend on fully taking Ariate's advice regarding analyzing societies, "What these people say or write about themselves, their society or even other people unarguably constitute who they are and what their society is, and therefore must be considered an integral part that must be examined when a particular society is under scrutiny" (Ibid: 198). The key for my examination will be how Muslims interpreted the fall of the Ottoman Empire and the ways in which they reacted to it which will determine the severity of a crisis in Muslim society at that time.

Two dissertations recently published address my question more closely than the aforementioned scholars. The first, "Islam and the politics of secularism: The abolition of the Caliphate", by Nurullah Ardic, exhaustively chronicles domestic politics in Turkey and its international ramifications from 1908-1924. Ardic successfully argues that in early $20^{\text {th }}$ century Turkey and the Middle East, the relationship between Islam and secularism was accommodation, not confrontation (Ardic 2009: 2). He demonstrates this by studying the transformation of religious discourse where the role of the sacred in the public sphere was re-defined, not rejected (Ibid: 49). A thorough analysis of Turkish politics is complemented by a study of Muslim societies he describes 'on the periphery', mainly Egypt and India. Ardic remains focused on how the importance of the Caliphate was marginalized, not on how its removal did or did not inspire social transformation. However, his survey of Arab political thought on the Caliphate is commendable, even if it seems lost in his trenchant deconstruction of religious rhetoric of the period. These 
brief segments in some of his chapters demonstrate that social and political mobilization was an evolving process after the Caliphate was removed (Ibid: 347-351).

The second dissertation, "Loss of Caliphate: The Trauma and Aftermath of 1258 and 1924", by Mona Hassan, compares the destruction of the Abbasid Caliphate in Baghdad with its disestablishment in Istanbul. Hassan details the spectrum of reactions from Europe, South Africa, and South Asia, to reflect the impact the loss of this institution had on believers. Her excellent analysis while expansive, does not stretch beyond the year of 1924. The few exceptions, mostly in Chapter four, frame the PanIslamic actions to reconstruct a new Caliphate. This includes King Hussein's claim in the Hijaz, and the various international Islamic conferences formed beginning in Cairo (Hassan 2009: 187-198). However, there is no deep reflection on how the removal of the Caliphate spawned national movements in some of the most important countries studied. In no way should this discount the panoramic view Hassan reveals of the Islamic world in 1924, it merely was not the focus of her thesis.

My operating hypothesis is that the dissolution and abolishment of the Caliphate had a significant impact on the minds of Muslims and signified the need to mobilize civil and religious organizations to protect the political and institutional importance of Islam. This was done in different ways but with the same goal of preserving religious practices and thought in an age without the assistance of a generally recognized Islamic polity. As my research question suggests, there is no "one size fits all" answer, the answer is dependent on the country and context they find themselves in. Each country that I intend analyzing had a different position vis-a-vis colonialism but also with power in the Islamic 
world. Egypt for example had more power than any other nation outside the capital of the Ottoman Empire, but was heavily colonized by British forces. Egypt had two factions to deal with, the colonizing power and dissension within their own ranks. Turkey however was never colonized, and literally did an about-face regarding the state's relationship with religion. They were led by a controversial yet powerful figure able to lead one singularly defined unit in a new direction.

One of the goals or achievements I believe the paper will accomplish is to problematize the prevailing assumption or inclination by some to make Islam a monolith. There can be no singular answer to a question which by its very nature presupposes unity. I am not saying I believe there is a universal Muslim community, which seems more of a metaphysical, spiritual question. By breaking down this question and examining three case studies [Turkey, British India, Egypt] I am implicitly stating that when one considers how Muslims think or conceptualize their world, we must be sensitive to place and context.

\section{1: Methodology}

The overarching methodology applied to this subject would be neopositivism. The goal behind this essay is to prove as Jackson writes is how, "a causal connection shows itself in systematic cross-case correlations between specific factors" (Jackson 2011: 41). What were the reactions to the fall of the Caliphate, and did this serve as a catalyst for social mobilization? I am attempting to heed Jackson's warning about being 
overly concerned about foundational assumptions. To achieve this I am keeping my assumptions as broad as possible and even introducing a case selection (India), a country which I have very little knowledge of in the period under study. The intent behind this is to not so carefully structure my argument that the result is predetermined, but rather let the hypothesis "encounter the world in terms of [its] theoretical implications" (Ibid: 59).

Though I see many aspects of neopositivism in my study, I also believe there will be strong elements of analyticism embedded in the way I present my findings. Part of my research will involve process-tracing and discursive analysis. While I will not disregard the hypothesis testing of neopositivism wholesale, I do believe my research will result in "crafting analytical narratives" and ordering "analytically the empirical data in accord with a model the worth of which lies not in its correspondence to the world, but in its pragmatic consequences for ordering the facts of the world" (Ibid: 115). Though analyticism is opposed to comparison, it can be done "in the pursuit of what Charles Tilly calls 'individualizing comparisons' that is useful for 'grasping the peculiarities of each case"” (Ibid: 153).

The method I will be employing is the middle range theory of historical institutionalism (HI). This is fitting for several reasons. Primarily, as Sven Steinmo points out, "HI scholars tend to be interested in important and relatively rare events" (Steinmo 2008: 134). For nearly the first 1300 years of Islam's existence, its believers and indeed the structure of the religion relied upon the political and religious leadership of the Caliphate. It is only until recently that Islam has existed without one. One of the 
purposes of the essay, similar to HI, is not to predict future events in Islam, but rather explain the significance of what has already taken place.

This is where the concept of 'critical juncture' in HI is useful and necessary. I hypothesize that the abolishment of the Caliphate, a major religious institution in Islam, served as a catalyst for social mobilization and a reconceptualization of Islam's role for its followers. While it seems ironic to use the theory of historical institutionalism to explore the destruction of a historical institution, the concept of a critical juncture serves as a proper framework to analyze "a period of significant change, which typically occurs in distinct ways in different countries and which is hypothesized to produce distinct legacies" (Capoccia and Kelemen 2007: 347).

Rather than use counterfactual analysis to examine the hypothesis, it will be tested by assessing whether it meets the necessary elements of a critical juncture. This is explicit in the hypothesis itself; did the demise of the Caliphate create a cascade of effects in the Islamic world? Two of the elements necessary to consider are whether it created a generative cleavage, and engendered change that was significant, swift, and encompassing (Hogan 2006: 664). The key instrument to ascertain whether this happened is process tracing that identifies which decisions were most influential and "reconstruct the consequences of the decisions that were taken" (Capoccia and Kelemen 2007: 354, 357). 


\section{2: Data Acquisition}

Ideally, the sample size for this type of study would encompass the major population centers of Muslims in the world. This would ensure I include different countries, geographical zones, and political entities. My selections are three countries (Egypt, Turkey, British India).

Egypt is almost a default selection as this country is a major center of gravity in the Arab and Islamic world. The oldest institution of Islamic learning is located in Egypt and some of the major religious organizations in the Islamic world emanated from its capitol in Cairo. It is the most populated country in the Arab world and was the most affected by colonialism, an independent variable in my study.

Turkey could be viewed as selecting the dependent variable, as the Ottoman Caliphate was situated here and was dissolved by the nation's ruler. However Turkey also serves as an explanatory agent for why the Caliphate was abolished and serves as a contrast to Egypt. Turkey was never colonized as Egypt was, and even up until the present has maintained a somewhat lacite political culture relative to the countries surrounding it.

The final area of analysis would be South Asia. Selecting a group or unit to analyze is a bit complicated as neither Pakistan nor India had become a nation at this point. Because of this factor, I am selecting the Khilafat movement which lasted from 1919-1924. This group of South Asian Muslims attempted to revitalize or in fact move 
the Caliphate from Istanbul to another location before it was vacated. An analysis of the Khilafat movement would uncover whether the dissolution of the Caliphate united Muslims in South Asia or actually disintegrated an ongoing movement. Another factor I will have to explore is the Muslim League, an organization founded in the first decade of the $20^{\text {th }}$ Century. This group existed before, and continued to remain a force in Pakistan after the Khilafat fell away. Whether the Muslim League was affected by the end of the Caliphate and participated with the leaders of the Khilafat trend in Pakistan needs to be discussed.

Cases that deserve to be studied but will be omitted are countries in Southeast Asia like the Philippines, Malaysia, but in particular Indonesia. There is some recent literature that discusses the linkage between the fall of the Caliphate and political movements inside Indonesia (Kersten and Al-Rasheed, 2013). The main reason I will not address this case study is largely due to time and space constraints. There is too much that needs to be analyzed and connected among the existing three cases. The conclusion will discuss other elements regarding the fall of the Caliphate and areas deserving further research. 


\title{
CHAPTER 3
}

\section{FALL OF AN EMPIRE RISE OF A NATION}

\author{
3.0: The Fall of the Ottoman Empire
}

The Ottoman Empire had been for many years the most stable and dominant force in the world. Despite its many successes, the Ottomans declined as a result of the formation of independent movements, foreign intrusions, and a weakening infrastructure. The Hatti-Sherif declaration inaugurated what would be known as the Tanzimat (Reforms) lasting from 1839-1876. It was an attempt to harness the modernizing dynamism European countries were applying to their military and economic spheres. The aspiration was to address the administrative shortcomings of the Empire while animating its populace. It was one of the last desperate political efforts to galvanize its subjects as one people rather than several disparate movements searching for power and self-identity.

A series of events and Ottoman policies precipitated the cause and need for the reforms called for in the Hatti-Sherif edict. The Ottoman Empire was less concerned in maintaining a national, 'Ottoman' mentality by its subjects, and more focused on flexibility and efficiency in their administrative affairs (Cleveland 2004: 44). Over time this would leave open the opportunity for local communities and millets to take on their own separate identity. External factors like the penetration of European merchants and 
exploitation of its raw materials caused a loss in state revenues (Ibid: 49). One of the most decisive moments came following the successful invasion of Napoleon in Egypt in 1798. The outnumbered, but well-armed French forces, defeated a large, experienced indigenous force on its own territory. Even after the British removed the French forces, western influence remained. Coupled with the growing decentralization resulting from the invasion and aggrandizement from the Janissaries, the Ottoman rulers became convinced that in order to stabilize the region, adoption of some western technology and military reforms would set the Empire on the right track (Ibid: 57).

The aims of the Tanzimat period were threefold; reform the military establishment, the tax system, and replace the traditional judicial system with a more equal and secular one. Implicit in these decrees was the idea of unifying the empire and appeasing demands from separate parties for a more representative government. The government hoped that by meeting these demands they would prevent any widespread rebellion or fractionalization from within the empire (Davison 1988: 118). There were signs of this taking place already. Rebellions in Crete and other European groups like the Serbs and Romanians threatened to divide key areas of the empire (Ibid: 119).

A key theme of the Tanzimat was equality. One effort to ensure this was provide the opportunity for those previously denied to serve in the armed forces. "It is the inescapable duty of all the people to provide soldiers for the defense of the fatherland [vatan]." The belief was if the citizenry held a stake in the 'fatherland' they would be willing to fight for it and be unified in loyalty to the country, instead of their specific ethnic group. The last message of equality for all in the country is dictated in a revision 
of the tax laws. "It is therefore necessary that from now on every subject of the Empire should be taxed according to his fortune and his means, and that he should be saved from further taxation. Throughout, no distinction was made between Christian and Muslim, or noble and peasant. This was designed to meld together the two distinct groups as one, and create a shared identity and heritage in the future of the Ottoman Empire.

Unfortunately for the rulers, it did not succeed. The Greeks and Cretans specifically did not call for equality, but autonomy and separation from the Empire (Ibid: 119). This became even more evident when the Christians did not come out in waves to serve on behalf of the Sultan. Christians preferred to pay the exemption tax rather than serve as equal members in the military service (Ibid 123-124). Furthermore, the reforms of the Tanzimat were imposed by the political elite on society. While many of the reformers, collectively called Young Ottomans in the latter years of the Tanzimat, enjoyed the company and influence of European elite, many Muslims within the empire interpreted these broad based reforms as surrendering their Islamic heritage (Zürcher 200: 66-67).

The Tanzimat disproportionately favored those outside the Empire and the elite class who were already benefiting from current corruption and graft. They were the only ones connected and skilled enough to adapt to the changing tide. Foreigners were permitted to own land within the Empire while poor economic policies led to increasing indebtedness to European powers. The changes to Ottoman bureaucracy were implemented in such a haphazard and high-handed fashion that the Young Ottomans 
$[\mathrm{H}] \mathrm{ad}$ taken away the rights which the people enjoyed under the old, Islamic order, and had given them none of the rights which belonged to the European system of government that they were introducing. By their actions they were discrediting Islamic government in the West, and Western government among Muslims (Ibid: 171).

The natural backlash to such well-intentioned but mismanaged reforms was the consolidation of power under Sultan Abdulhamid II. Bolstered by severe territorial losses to the Russians and Serbian uprisings, Abdulhamid II managed to abolish the first Parliament and Constitution in Islamic history two years after it was created in 1876 (Ardic 2009: 63-64). Despite his severe oppression of opposition movements and censure of the press, Abdulhamid II continued to reform and modernize the Ottoman Empire almost along the same lines as the Young Ottomans. However, in contrast to the Young Ottomans, he anchored his policy along a Pan-Islamist narrative that endeared him to Muslims domestically and abroad.

Abdulhamid II's nearly thirty year reign ended with the rise of the Committee of Union and Progress (CUP) and a wave of mutiny infecting multiple Ottoman Armies. This was precipitated by continued economic hardship leading to high inflation, delayed payments for government employees, and general discontent (Zürcher 2000: 90). The 1876 constitution was restored and the Young Turks instituted several changes that would have a lasting impact even after the Ottoman Empire was dissolved; an increased role for the military in politics and continued imitation of the European model for civilization.

While the Ottoman Empire was fragmenting internally, Western countries continued to lay claim to its outlying territories. In response, the Ottomans sent military 
contingents to quell rebellions and fight European invaders in various parts of the Empire. Their international engagement culminated in their involvement in World War I. The Ottoman Empire signed a defensive treaty with Germany to end their isolation regarding developments in Europe and in hopes of reversing Russian victories on its northern border (Ibid: 111-112).

Within a few years, the Axis powers surrendered and the independence and sovereignty of the Ottoman Empire was no more. The armistice of Moudros and treaty of Sevres solidified not only the partitioning of the greater Middle East but the occupation of Istanbul itself. The Greek occupation of Izmir in 1919, a land historically held by the Ottoman Empire, sparked the Turkish war of Independence along three fronts; the Allied powers occupying the capitol, the nominal Ottoman government, and the nationalists who coalesced in Ankara $^{3}$ (Zürcher 2000: 119; Lewis 1968: 241). A rival power center was established in Ankara, rejecting the conditions outlined in the treaty of Sevres and the last Ottoman parliament being dissolved in April 1920. Within a few weeks, a Grand National Assembly was established in 1920 to solidify nationalist resistance and rescue the Caliph of Islam from occupation (Lewis 1968: 241). In turn, the chief Mufti at the behest of Istanbul issued a fatwa declaring the nationalist movement illegitimate and sanctioning their murder. ${ }^{4}$

\footnotetext{
${ }^{3}$ The nationalist movement benefited from "The General Staff's policy of posting its best commanders to Anatolia" (Rustow: 1959, 538)

${ }^{4}$ This decision was circulated throughout the country and even air dropped by Allied aircraft (Kinross 1964: 248)
} 


\section{1: The Rise of Turkey}

It was at this juncture in history Mustapha Kemal, later called Atatürk, 'father of the Turks', crafted his legacy as the founder of a new nation. Unlike other leaders in his day, Atatürk had accumulated an impressive record spanning his numerous deployments in various parts of the Empire. "His defense of Gallipoli against invading forces many times stronger had saved the Ottoman Empire from collapse...later he stabilized the front in Eastern Anatolia, where many other generals had gone down in defeat" (Rustow:

1959, 536). The rapidity of the nationalists success against Greek armies and elements of Istanbul compelled the Allies to plea for an armistice (Mango: 2000, 344).

The nationalist movement in Ankara was able to accomplish not even what the political and religious authorities in Istanbul could. Namely, defend the historic borders of the Turkish speaking peoples and remove the spirit of defeatism which plagued the country. They stood up against not just the Allied forces in Istanbul, but Ottoman leadership who created an 'Army of the Caliphate' whose sole purpose "was to counter and destroy the Ankara forces" (Özoğlu 2011: 42). The movement gained international recognition by reaching agreements with Russia, France, and a pending treaty with the Allied powers.

Despite being a triumphant military commander, Atatürk had no desire to recover lost territory from other Ottoman provinces. In fact, during the campaign he postponed or even canceled operations deemed unnecessary saving lives in the process (Mango 
2000: 344). Instead of expanding the war effort to Syria and Iraq, Atatürk defended his efforts by stating that "The government of the Grand National Assembly of Turkey has a firm, positive, material policy, and that, gentlemen, is directed to the preservation of life and independence... within defined national frontiers" (Lewis 1980: 30). He couched part of his argument on the sheer incapacity for further military adventures, but also on past failures of fulfilling a misguided Pan-Islamist vision of vast territorial unity. "We have brought the hatred, rancor, and malice of the whole world on this country and this people, we did not serve pan-Islamism. We said that we had and we would, but we didn't...let us return to our natural, legitimate limits. And let us know our limits. Gentlemen, we are a nation desiring life and independence. For that and that alone may we give our lives" (Ibid, 31).

Within a year of this speech Atatürk began openly stating to the press his plans to establish a republic and abolish the Caliphate (Zürcher 2000: 159). Before this could be accomplished, the first hurdle was separating the temporal, political authority embodied in the Sultan. Removing the Sultanate was a priority of Atatürk, (Kinross 1964: 387), and his plan benefited greatly by a decision of the Allies to recognize both the Sultan's government in Istanbul and the Grand National Assembly in Ankara by inviting them to negotiations for the Treaty of Lausanne (Atatürk 1927: 575, Lewis 1968: 257, Zürcher 2000: 160). "At this the deputies exploded in wrath. Sixteen orators in succession denounced the action as a manoeuvre of the Sultan to divide the country in the eyes of the foreigner" (Kinross 1964: 395). 
Once again, Atatürk's plans were advanced by incidental involvement of foreign powers. The Grand National Assembly criminalized the existence of the Sultanate by passing several laws after removing it permanently in November 1922. The first, occurring immediately after the Allied actions, stated that "The Turkish people consider that the form of government in Istanbul resting on the sovereignty of an individual had ceased to exist on 16 March 1920 and passed forever into history" (Lewis 1968: 259). The second, passed the following spring, made campaigning a return for the Sultanate a criminal act (Zürcher 2000: 159).

The acts of the Grand National Assembly served as a prelude to the future of civil society and social change for Turkey. Mobilization in opposition to, or in parallel with the existing government was either preempted or stymied via legislation, edicts, or judicial constructs of the Turkish government. As crises developed in the coming years, Atatürk and the central government minimized the legal space in which contesting visions could develop. The new government began the process of protecting "its decisions by classifying any opposition as high treason" (Özoğlu 2011: 82). Legislation was drafted for the sole purpose of undermining the platforms of the government's opponents

A continuation of this policy is evident in Atatürk assuring that the seats of the Grand National Assembly in Ankara reflected his interests. Capitalizing on his victory in the Independence War, Atatürk formally announced the formation of his political party, the People's Party, in December 1922, and personally reviewed all candidates for the 1923 election (Zürcher 2000: 159). 
With the removal of the strongest opposition group in Parliament after the 1923 elections, there was little impediment to introduce legislation to abolish the Caliphate. However, the opportune time did not present itself. Soon after the establishment of the Grand National Assembly in 1920, Atatürk pondered the formation of a new government. "In reality, it was a question of acknowledging the collapse of the Ottoman State and the abolition of the Caliphate. It meant the creation of a new state standing of new foundations. But to speak openly of the position as it revealed itself might eventually jeopardise the goal we were aiming at" (Atatürk 1927: 379). Even discussions with those in his inner circle reflected the fact that there remained a strong sentiment towards the office of the Caliphate (Kinross 1964: 388).

The separation of the Sultanate and the Caliphate created an unnatural separation. Throughout the history of Islam, the Caliph was a political as well as religious authority. After Turkey was proclaimed a Republic on October 29, 1923, the question of the Caliphate's role in society resurfaced. What stuck out quite prominently in Atatürk's mind were the "journalists in Constantinople who had the idea of making the Caliph play a role" in the new government (Atatürk 1927: 667). Other parties were interested in the maintenance and elevation of the Caliphate as a religious symbol and political force. A pamphlet entitled 'The Islamic Caliphate and the Grand National Assembly' was printed in early 1923 which called for the national assembly to serve as an "advisory council to the Caliph and the Caliph himself as President of this Assembly and thereby as the Head of the State" (Ibid, 588). This concept was anathema to Atatürk's goals of independence and the lack of religious influence in the direction of the new republic. However, the 
many rumblings within Turkey still did not alter the political climate enough to necessitate such a historical maneuver as removing the Caliphate.

There is wide consensus that what prompted, or at least accelerated the final disestablishment of Islam in Turkey and the collapse of the Caliphate, was a letter from two influential Indian Muslims published in three dailies ${ }^{5}$ (Kinross 1964: 438, Lewis 1968: 263, Zürcher 2000: 167, Ardic 2009: 134, Mango 2000: 400). ${ }^{6}$ The authors stressed that "Islam, as a great moral and cohesive force, is losing among large sections of the Sunni population, owing to the diminution in the Caliph's dignity and prestige" (Toynbee 1925: 571). They did not want "the powers of the people's representatives...curtailed" merely the religious headship maintained alongside it. Their reasoning for this request was to prevent "the disintegration of Islam and its practical disappearance as a moral force in the world." The Caliph for fourteen centuries was head of the Sunni congregation and that "This mystical element cannot be eradicated from the Muslim mind without creating discord in the world of Islam." Upholding this long tradition would not only benefit Islam but also endow "the Turkish state unique strength and dignity" (Ibid: 571).

The widespread publication of this letter was interpreted as interference in the domestic affairs of a newly established, sovereign Turkey. Within days, the editors of the newspapers suspected of complicity were arrested and brought before an Independence

\footnotetext{
${ }^{5}$ Less than two weeks before this letter was published, the newspaper Tanin, led with an article titled 'And Now the Question of the Caliphate' which in Ataturk's eyes was trying to "discredit the Republic in the eyes of the nation" (Atatürk 1927: 669).

${ }^{6}$ Zürcher states the "two eminent Indian Muslims, Ameer Ali and the Aga Khan" sent their letter in December, as does Mango, while Lewis cites late November.
} 
Tribunal on charges of high treason. The letter was sent from London, which Atatürk and the Prime Minister "interpreted as the British government's intervention into Turkey's internal affairs" (Ardic 2009: 134). The journalists were eventually acquitted, but their actions spurred a flurry of political activity. Over several months, Atatürk traveled the country and prepped his cabinet for the fateful day of March 3, 1924, when the Caliphate was officially abolished.

The widespread shock and resentment partially stemmed from the way the Caliphate was dissolved. There was no outreach to other Muslims or attempts to build consensus on how best to preserve the institution and retain sovereignty. Atatürk rejected this notion of unity as some Muslim protectorates sided against the Ottoman Empire in World War I. Additionally, the removal of the Caliphate came not by the hands of foreign invaders like the Mongols sacking the Abbasid Caliphate in Baghdad, but by a Muslim whom they believed promised to rescue Islam from its subjugated status in colonized countries throughout the globe.

In fact, this was the stated policy of the Grand National Assembly and the promises of Atatürk himself. Four days after the British completed the occupation of Istanbul, Atatürk published a proclamation stating that "We shall have won the applause of mankind and shall pave the road to liberation which the Islamic world is yearning for, if we deliver the seat of the Caliphate from foreign influence..." (Atatürk 1927: 363). A fatwa signed by Bursa ulama, designed to counter the fatwa of the Sheikh Al-Islam, stated that it was "the duty of all Muslims to help rescue the Caliph from captivity in Istanbul by the enemies of Islam" (Ardic 2009: 413). Similarly, in a telegram two days 
before the Grand National Assembly was opened, Atatürk stated "The duties of the National Assembly will be of vital description and of the utmost importance — such as, for instance, securing the independence of our country and the deliverance of the seat of the Caliphate and Sultanate from the hands of our enemies (Atatürk 1927: 373). It is difficult to overstate the shock to the Islamic consciousness, when a Muslim who promised to uphold the most symbolic political structure of Islam is the one chiefly responsible for its downfall.

Atatürk's decision did not come out of the blue. Soon after the formation of the People's Party, Atatürk published a manifesto with nine articles (Lewis 1968: 259). Conspicuously absent from its contents is any mention of diluting the influence of Islam in society. "This programme contained essentially all that we have accomplished and applied until today. There were however, certain important and fundamental questions that were not included in the programme, such as the proclamation of the Republic, the abolition of the Caliphate, the suppression of the Ministry of Seria [Sharia], the closing of the madrassas...I did not think it right, by prematurely introduction these questions into the programme, to give the ignorant and the reactionary the opportunity to poison the whole nation" (Atatürk 1927: 598) While the timing may have been influenced by foreigners, in Atatürk's mind it was a fait accompli. This was an inevitable stage of development as Turkey matured as a modern nation in the international system.

There were three main reasons Atatürk justified the removal of the Caliphate. Firstly, it undermined the independence of a sovereign, Turkish nation. Shortly before the abolishment, Atatürk traveled the country and would state "We cannot allow any 
person, whatever his title may be, to interfere in questions relating to the destiny, activity and independence of the new State...the people of New Turkey, have no reason to think of anything else but their own existence and their own welfare. She has nothing more to give away to others" (Atatürk 1927: 592-593). Secondly, the 'civilized' world would not accept Turkey as a modern nation so long as the Caliphate remained a part of its heritage. Justifying its removal, Atatürk remarked, "As for the Caliphate, it could only have been a laughing-stock in the eyes of the really civilized and cultured people of the world" (Ibid: $18)$.

Lastly, Turkey had paid the price for hundreds of years as custodian of this institution. In Atatürk's mind, it was no longer their burden to bear. No one was more familiar to the hardships incurred by the Turkish people than one of its most noted commanders. Atatürk likely held a heavy grudge against the Ottoman leadership, who despite his counsel, decided to sign an alliance with Germany in World War I. While stationed in Bulgaria, Atatürk sent a message to the War Minister advising him to stay neutral, with the possibility of intervening later against Germany (Kinross 1964: 78, 514). Atatürk benefited from seeing events unfold while stationed in Europe and visiting Paris. Quite presciently, Atatürk noted before the war "We declared mobilization without determining our aims. It will be harmful for us to maintain a large army for a long period. The outcome of this war will not be certain for us or our allies" (Ibid: 78). Rather than wait the conflict out or side against the Central Powers, Turks heeded the call of their Caliph. A fatwa declaring a 'Great Jihad' was read aloud in the mosques and spread throughout the Muslim world (Ardic 2009: 320). 
As Atatürk rose through the ranks of the Ottoman military, he was deployed multiple times to preserve the fraying ends of a vast empire; In Libya (1911), against the Bulgarians in the First Balkan War (1912), Battle of Gallipoli during World War I (1915), against the Russians (1916-1917), and Palestine (1918) (Ibid: 151). Given his experience, it was natural for him to argue against the existence of the Caliphate in such terms.

"[N]either Turkey nor the handful of men she possesses could be placed at the disposal of the Caliph so that he might... found a State comprising the whole of Islam. The Turkish nation is incapable of undertaking such an irrational mission. For centuries our nation was guided under the influence of these erroneous ideas. But what has been the result of it? Everywhere they have lost millions of men. 'Do you know,' I asked, 'how many sons of Anatolia have perished in the scorching deserts of the Yemen? Do you know the losses we have suffered in holding Syria and the Irak and Egypt and in maintaining our position in Africa? And do you see what has come out of it? Do you know? (Atatürk 1927: 592).

While Atatürk certainly held animosity towards the ruling establishment of Islam, he was not against the existence of the Caliphate per se, but the weight of its responsibility on the new Turkish Republic. "The persons who bear the title of Caliph might flee into foreign countries. Our enemies and the Caliph can join and together attempt any enterprise, but they can never shake the administrative system of New Turkey, nor her policy, nor her power” (Atatürk 1927: 585). Hakan Özoğlu's study of American archives reveals that "Kemalists were promising to support Seyyid Ahmet Sanussi for his bid for the caliph as long as he promised to support the Ankara government and reside outside of Turkey." Sanussi reportedly refused, preferring the current caliph to remain in Istanbul. "If this is true, it shows that Ankara was more 
interested in uprooting the Ottoman dynasty than in abolishing the Caliphate" (Özoğlu 2011: 5-6).

\section{2: Internal Opposition}

Within a few months, the Grand National Assembly proved they were not just against the Caliphate, but any critical voice that would challenge the authority of the new Ankara government. A tool at their disposal was a stipulation in the Treaty of Lausanne that allowed the new government to declare 150 individuals persona non grata. Topcu Ihsan Bey, who is believed to have originally thought of the list, stated in deliberations that hundreds committed treason during the war of Independence but that "[W]e should focus on those who potentially can harm us in the future" (Özoğlu 2011: 28-29).

The list included a diverse array of professions (government officials, policemen, journalists), but with one commonality; past or potential disruption of the newly formed government. The list began with members of the 'ulama class, most notably the former Sheikh al-Islam, Mustafa Sabri. The second group contained high ranking members of the Army of the Caliphate, formed in Istanbul to defeat the nascent nationalist movement in Ankara. The third group were journalists, critical of the Grand National Assembly and closely associated with the Istanbul elite. Despite the fact that these individuals had no position to challenge the new government, they were eliminated out of prudence, and to intimidate those who still remained (Ibid: 43, 49, 67, 75). 
While the abolishment of the Caliphate removed an immensely influential and popular symbol in society, additional legislation in the following months ensured that the remaining 'ulama would hold no position of power in society. The assembly supplanted Islamic legal and educational institutions by closing all religious schools, the Ministry of Religious Affairs, and religious courts. These were replaced by state sponsored secular curriculum and the Department of Religious Affairs. Through this institution, Ankara effectively controlled the religious narrative by appointing religious leaders, monitoring sermons, and serving as custodian of the mosques (Ardic 2009: 489).

In a span of two years Turkey quickly transitioned from being the seat of a defeated Islamic Empire to a secularized constitutional Republic where religion was controlled by the state rather than led by it. These radical changes in society created friction within the capitol. Eight months after the Caliphate was removed Turkey's first opposition party was formed.

Ironically, it was some of Atatürk's closest allies during the War of Independence that established the Progressive Republican Party (PRP) (Mango 2000: 419). Though it was less than a year after the PRP effaced Islam as a cultural pillar, the purpose of the PRP was not to mobilize a religious counter-movement, but balance the aggrandizement of Atatürk and his party. The party's manifesto reflects this concern by stating that "representatives, elected by the nation, have not been able to find a way both to draw up laws and to execute them" (Zürcher 1991: 136). The result has been "the part which concerns the execution [of the law], to [a] restricted group they have separated from their 
midst." One of the drawbacks "is the possibility that some form of tyranny establishes itself and takes away from the nation its rights."

Therefore, the cause of the party is "to save them [representatives] from the temptation to lose their civil courage while striving for personal gain and to prevent the executive from exceeding its competence, in short: to bring the nation and the executive into a state of continuous competition with each other" (Ibid: 137). The PRP sought to restore the system of checks and balances by explicitly making their program about the rule of law and sovereignty of the people from their government.

The PRP emphasized this through 58 articles in their program and 64 party statutes. Article one of the program states that Turkey is "a republic based on the sovereignty of the people" and the party's statutes recognizes that sovereignty requires "the strengthening and improving [of] the rule of law and order in the country through the guarantee of a just application of the laws" (Ibid: 138, 146). The end purpose as indicated in the PRP's platform is to safeguard general liberties (article four) and the rights and interests of individuals (article eleven) even if they are government employees. The party's ideology emphasized liberal principles, economically and socially, and promoted a small state structure that decentralized the actions of the central government. The sole mention of Islam or religion's role in society is tersely mentioned in point six "The party respects religious beliefs and convictions." This conservative stance contrasted sharply with the recent actions of the GNA, and was used against it less than a year later when a rebellion fomented among Kurdish nationalists. 
The PRP was widely embraced in Istanbul. Within three months of its inception, branches were created in eleven districts (Zürcher 1991: 63). Atatürk allowed the opposition party to form, but took steps to undermine its significance and strengthen his control of the RPP. Shortly after the PRP's formation, the RPP passed several propositions to quell dissension and ensure unity of thought. Interpellations would only occur, and be passed to the GNA, only if a majority agreed in closed sessions (Ibid: 62). Furthermore, members of the RPP were not allowed to make statements contrary to the principles of the party. A court was established within the party to regulate compliance to these proposals, and mediate disputes between fellow party members (Ibid).

Clashes quickly developed between the two rival parties, mostly arising from perceived authoritarian actions by the government. Less than a month after the opposition was established, the government shut down two newspapers. When PRP members challenged the grounds for this action, the government stated they published articles that threatened the security of the country (Zürcher 1991: 76). For its brief tenure as Turkey's first opposition movement, the PRP movement did not threaten the government as much as it "attacked what it saw as undemocratic and authoritarian tendencies in the government, such as too wide powers for the Ministry of Interior, the closure of newspapers, rejection of the election of an anti-government candidate and government interference in the elections themselves" (Ibid: 79). 


\section{3: Religious Revolt}

Ironically, the rise of Turkey's second political opposition, albeit a violent one, provided the means and justification to eliminate all dissident movements. Moreover, this brief period allowed Atatürk to prevent the rise of organizations or any mobilization that would use religion as a basis for its foundation. While the Kurdish revolt led by Sheikh Said existed for only a few months, its legacy on Turkish society lasted for decades. The actions of several tribes in Eastern Turkey set back efforts to reintroduce Islam as a political force and ruined the chance of any opposition forming for years.

Relations between Atatürk and the Kurds were not always hostile. The nascent nationalist movement depended on Kurdish support during the war of Independence. Robert Olson argues that Atatürk may not have succeeded militarily if not for their support in key transit zones in Eastern Anatolia (Olson 1989: 36-38). In return for their support, he promised the Kurds equal rights with the Turks and restoring Islam to its proper place (Ibid: 36$)$.

Despite promises to the contrary, the Kurds found themselves on the receiving end of the new government's centralization and secularization efforts. Kurds were losing representation not only in the National Assembly, but in local elections as well. As a result, a secretive Kurdish movement called Azadi, founded between 1921 and 1923, began growing branches in various parts of Turkey (Ibid: 42, Van Bruinessen 1992: 280).

Prior to the event, Kurdish officers told British Intelligence eleven reasons for their growing resentment. Some of the explanations provided reflect the Turkification 
policies of Atatürk which banned the use of Kurdish in schools and courts, and disrupted the integrity of Kurdish tribes by forcibly relocating and setting them against one another (Olson 1989: 43-44). Another reason listed was closing down religious institutions "which were the only remaining source of education for the Kurdish race" (Ibid).

There is some argument among scholars whether nationalism or religious fervor was the strongest reason for the rebellion. However, this argument presents a false dichotomy as Islam was the basis of power and social organization. By disrupting this foundation the effects were simultaneous and reciprocal. For example, the "disestablishment of Islam, which supplied the sheikhs/chiefs with the bases of their power, especially tax-gathering privileges," removed a source of income they could use to influence and govern their local population (Olson and Tucker 1978: 200).

Perhaps the most apt explanation for the Kurdish rebellion is of an incipient nationalist movement agitated by the undermining of religious authority. One of the most cited scholars on this issue states while "The revolt was neither a purely religious nor a purely nationalist one...nationalist sentiment arose out of, or was at least stimulated by, religious feeling..." (Bruinessen 1992: 298-299). There was unquestionably a mixture between politics and religion, however there is no doubt that the removal of the caliphate had profound effects on the psyche of the Kurds, and was a key variable that accelerated momentum for their cause.

One of the 11 reasons cited by the Kurdish officers was "The abolition of the Caliphate by the Turkish Government, which has broken one of the few remaining bonds between the Turks and Kurds" (Olson 1989: 44). While the Azadi organization and 
others unaffiliated called for an independent Kurdistan for years, "it was not until the caliphate was abolished by Mustafa Kemal (Atatürk) in 1924 that a wave of more or less nationalist-inspired revolts erupted in Kurdistan" (Bruinessen 1992: 269). Thus, "It is no surprise that when the rebellion emerged, the objective most often referred to was the restoration of the Caliphate and hence of established Islam" (Olson and Tucker 1978: 200).

Sheikh Said was the nominal leader for the revolt due to his religious credentials, fervent nationalism, and great influence among a large group of tribes (Bruinessen 1992: 280). However, there were several tribes that refused to support him, partially because he elevated "the issue of religion above that of Kurdish independence" (Kinross 1964: 455). To gain supporters to his cause Said stated he was attempting to rescue and restore religion. He issued a fatwa declaring himself the representative of the caliph and Islam (Olson 1989: 108). Thousands galvanized under Sheikh Said in early February 1925 and seized several important cities in Eastern Turkey.

The assembly in Ankara responded swiftly and decisively. There was fear that the movement would spark similar outbursts in Istanbul and soldiers would desert from the Turkish army more than previously (Olson and Tucker 1978: 203). Martial law was declared on February $23^{\text {rd }}$, and over 35,000 troops were deployed to form a containment ring around the rebellious center (Bruinessen 1992: 290). Turkish air strikes and a superior armed force defeated the rebellion a mere few months after it started. Sheikh Said and many others were arrested, tried and executed. Said mentioned at his trial that 
the rebellion started because religion was losing its role in society, and defended attacking other Muslims because they were not true to their religion (Kinross 1964: 456).

The main legacy behind the Sheikh Said revolt was not the religious component to militant opposition, but the reaction and legislation enacted because of this relatively small scale revolt. "Hundreds of villages were destroyed, thousands of innocent men, women and children killed...Thousands of less influential Kurds were slaughtered without a trial." (Bruinessen 1992: 290-291). Despite the utter brutality of such actions, and others of the independence tribunals designed to convict those guilty of treason, the Law on the Maintenance of Order (Takrir-i-Sukun) would have the greatest effect on Turkish society.

On 4 March 1925, half way through the rebellion, TGNA passed a bill which contained three articles. The first bill gave carte blanche for the government to censure and remove any segment of society it deemed obstructive or uncooperative. It reads in part, "The government is empowered to prohibit on its own initiative....all organizations...initiatives and publications which cause disturbance of the social structures, law and order and safety and incite to reaction and subversion." Within two days of the law's passage, five newspapers were shut down, two in Istanbul, and journalists arrested. This despite the fact that "The public reaction to it [rebellion of the Kurds] throughout the new Turkey had been hostile. There had been little or no sign...of a sympathetic reaction...In Istanbul the students and the porters...had come out strongly against these manifestations of religious reaction" (Kinross 1964: 457). But as Lord Kinross notes soon after this observation, "But Kemal was taking no chances...The 
power of his opposition in Parliament and the press must now be vanquished as the rebels had been" (Ibid).

What is most notable in the midst of this national crisis is how smoothly one particular motion managed to pass the assembly. Prior to the passage of the draconian 'Law on Maintenance and Order', an amendment of the High Treason Law was passed on February 1925 which read in part "The founding of associations aimed at the use of the religion or the holy objects of religion as a basis or instrument for political purposes is forbidden." This included any written statements, publications or actions that would "create strife and intrigue among the people in any way whatsoever through the use of the religion..." What makes this fascinating is despite the effective ban on religious assembly, the law did not give rise to heated debate in the Assembly (Zürcher 1991: 84). The reason for this is twofold: 1) Oppositionists did not see this law directed at them but rather the rebellion in the East, which drew near universal condemnation, 2) Most politicians did not fear religious revolutionaries but the sitting revolutionary standing as head of the Assembly, Atatürk.

It was clear to many that the aim of the Law on Maintenance and Order "was not the handling of the Sheikh Said Revolt but rather the opposition" (Özoğlu 2011: 102). This is evident in a statement from the Minister of Defense on the day of the vote, "The most significant point that needs to be addressed [here] is the Istanbul Press, which is the main reason for the present day weakness [of our state]...” (Ibid, 103). The Law on Maintenance and Order was debated vociferously because the order gave the government "unlimited powers in every part of the country for a period of two years" (Zürcher 1991: 
84). While the prohibition on the political use of religion impacted a limited crosssection of society, one that had already been politically marginalized, this new law touched all segments of society and anyone who would oppose the Assembly.

Atatürk's command of the majority party in the Assembly assured the law's passage and with it "virtually eliminated any and all future opposition to Mustafa Kemal and to his inner circle" (Özoğlu 2011: 80). It particularly impacted the press where the newspapers operating in Istanbul decreased from fourteen to six. A member of the PRP remarked "As the press was deprived of the right to criticize and control the government, people stopped buying newspapers or treating them seriously. It was a kind of protest" (Mango 2000: 426). The law expired after its two year limit, but the arrests and censure of any oppositional elements, elected or civilian, ensured a controlled system of dissent that would last for the next twenty years (Zürcher 1991: 84).

The removal of the only formally recognized opposition party was a formality at this point. Near the end of April 1925 the PRP's offices were searched in Istanbul and the Assembly voted to close down the party less than two months later (Mango 2000: 426). In general, five different reasons were provided for its closure, three of which revolved around its respect for religious opinions and beliefs. Specifically cited was PRP's article six, which the assembly interpreted as a means of subversion through the political use of religion (Zürcher 1991: 91). They also connected the PRP platform with encouraging the Kurdish reactionaries in the East (Atatürk 1927: 718). Atatürk remarked a few years after these events, "Could any sincerity be expected from people who had adopted the following principle: 'The Party respects religious thoughts and religious 
doctrines?'...Has not the Turkish nation for centuries been dragged into endless suffering and into the pestilential swamps of obscurity under this banner, rescue only being possible through great sacrifices?" (Ibid: 717)

The influence of the PRP was not completely removed until 1926, when an assassination attempt on Atatürk was discovered in Izmir. While the attempt was organized by a small band of gunmen led by a former national assembly member, former PRP leaders were implicated in an attempt to damage their reputation. The members were charged, even though there was no evidence connecting them to the plot (Zürcher 1991: 92). Despite being cleared and released, the damage was done and the process to eliminate all political competition was complete (Özoğlu 2011: 123).

The complete disestablishment of Islam followed the end of the Sheikh Said rebellion. Seizing upon the momentum with the amendment of the high treason law, and his victory over the latest attempt to overthrow the Republic, Atatürk ordered the closing of all religious shrines, dervish convents (tekkes) ${ }^{7}$, and regulating the dress of existing religious institutions (Olson and Tucker 1978: 205, Zürcher 2000: 173). At this point in Turkey's history, nearly all religious behavior and action was consolidated and under complete control of the state. Individuals were allowed to practice their religion freely, but under strict government dictates. Articulating religion in a political arena was outlawed, as were certain settings such as the aforementioned shrines and convents.

\footnotetext{
${ }^{7}$ Bruinessen accounts the role of Sheikhs in the uprising as reason for this law being ordered (Bruinessen 1992: 291)
} 
Two months after the tekkes closure later he abolished the fez for the hat because in his words it "sat on our heads as a sign of ignorance, of fanaticism, of hatred to progress and civilization..." (Atatürk 1927: 721). Islam became socially acceptable only as a private affair, not public expression. Anything more would be detrimental to Turkey's acceptance in the world and its economic and political development at home. It was only after World War II that any legal opposition formed, and not until the late 1950’s Islam grew as a political and social movement (Zürcher 2000: 177, 193).

Besides the Kurdish rebellion in early 1925 , the fall of the caliphate did not generate a wave of religious outcry within Turkey. The greater fear, as seen in the PRP's program, was Atatürk's autocratic tendencies that remained unchecked by the GNA or society at large. A mixture of fortuitous timing and shrewd statecraft allowed Ataturk to effectively outlaw political expressions of religion. His secularist vision and political platform formed the basis of Turkish culture for decades to come. 


\section{CHAPTER 4}

\section{BRITISH INDIA}

4.0: Role of the Caliphate in India

Islam has been a part of India's history since invading armies entered its borders in the seventh century and made substantial incursions in the thirteenth century (Keay 2000: 181). From the $16^{\text {th }}$ to the $19^{\text {th }}$ century, the Muslim community was united by various leaders under the Mughal Empire. Despite its mostly Sunni composition, the major source of authority for Indian Muslims were the Mughals, not the Abbasids or Ottomans (Minault 1982: 5). However, the Caliphate was pivotal in bestowing legitimacy to regional leaders in times of strife, but served more of a purpose "as a symbol to which homage was rendered, as a banner for Muslim rulers to wave when threatened by conquest or internal dissension" (Ibid). In fact, the Mughals refused the Ottoman claim to "universal caliphate as they regarded themselves caliphs within their own realms" (Qureshi 1999: 14).

The Caliphate's role in Indian society took a fundamental shift after the last Mughal ruler was deposed following his support for the 1857 Indian rebellion. Partially a result of historical grievances with British rule, the development of a rifle cartridge requiring cow or pig grease offended Muslims and Hindus and increased animosity towards colonial rule. British interests existed in India since the $17^{\text {th }}$ century through the vast commercial exploits of the East India Company. However, after the 1857 
insurrection a royal decree by British Parliament granted all rights of the East India Company to the Queen (Keay 2000: 446).

The end of the Mughal Empire extinguished a historic structure of continuity and identify for the Muslim community. It was a seminal moment in the history of India, where for the first time in centuries Islam governed social affairs without political authority. This introduced a stage of educational reform and nationalism that expanded simultaneously because of their anti-colonial origin.

The loss of Muslim political power embodied in the Mughal Empire engendered three major educational institutions. All claimed to be the way forward for Muslims but differed in respects to the level of appropriation of Western practices. The Aligarh movement, started by Syed Ahmad Khan, believed that Muslims needed a Western education in conjunction with a religious upbringing (Talbot 2000: 92). The Deoband School fell on the opposite end of the spectrum in contrast to the Aligarh movement. Founded by a group of traditional 'ulama, their response to colonial intrusion was to reform Muslim education from within, eschewing English education and Western culture in the process (Minault 1982: 9). A key difference between the Aligarh and Deoband movements is that the former relied on British patronage to expand their main educational facility while the latter avoided it at all costs (Ibid: 25). The Barelvi movement which also emerged after the Indian uprising, was traditional like the Deoband, but focused on Sufi practices and was less institutionalized (Talbot 2000: 94).

Two political organizations formed to fill the vacuum left by the Mughal regime. The Indian National Congress (INC) formed in 1885 to present a united voice to the 
Imperial government. Many Hindu leaders believed their struggle was not just against British rule, "but against Muslim tyranny and misrule" and desired a body to represent their interests (Keay 2000: 457). In turn, a political branch of the Aligarh movement, the All-India Muslim League, was formed in 1906. Designed to counter the heavily Hindu character of the INC, the League stayed true to its Aligarh roots by declaring its loyalty to British rule and discouraging Muslim involvement in the INC (Minault 1982: 19, Talbot 2000: 93).

While there was historically a lack of recognition for the Ottoman Caliphate, policies of the British government and other events in the early $20^{\text {th }}$ century brought this religious office into the spotlight of Muslim Indian society. The first event was a British decision to deny Aligarh an affiliated University status with Britain. Aligarh officials refused to concede to the British demand of government control of University affairs (Minault 1982: 21). Additionally, the Balkan wars of 1911-1912 spurred rumors in the Urdu press of a Christian plot against the Ottoman Empire (Ibid, 22). Up to this point, Pan-Islam sentiments were agitated artificially as part of Britain's great game against the Russian Empire (Qureshi 1999: 18-30). Statements of support for the Ottoman Empire were visible in some of the local journals for a few decades before World War I, but it rapidly accelerated soon after the war ended. 


\section{1: The Occupation of Istanbul and the Indian Response}

Muhammad Ali and Shaukat Ali, products of Aligarh, led Indian Muslims in this Pan-Islamic fervor. Prior to Istanbul siding with the Central Powers, the Ali brothers supported Turkish war efforts against seceding parts of the Empire and battles in the Balkans. Their efforts to spur Islamic unity benefited from a domestic affair in India known as the Kanpur Mosque incident. This event united both traditional and westernized religious leaders against perceived assaults on religious liberty (Minault 1982: 46). It involved the destruction of a washing place in a mosque and the disregard by local authorities for Muslim complaints. The Ali brothers continued to agitate British authorities even discussing Turkish grievances against Britain after the former entered World War I (Ibid, 51). This led to their summary imprisonment during the war, which only enamored them more with the local populace.

Several events during the war resulted in new alliances and ultimately the emergence of a new social organization, the Khilafat movement. Within India, the INC and Muslim League agreed to a shared platform of goals known as the Lucknow Pact. It called for a proportional Hindu-Muslim representation in the government, and a set of goals to put India on the path to self-government. However, the most consequential event occurred outside India. Arab nationalism, particularly the Arab revolt led by Sharif Husain, Emir of Mecca, embodied the division in the Muslim community that many in India feared. Assured that an independent state would be recognized by the British, 
Husain led thousands of men against the Ottoman Empire and promised to liberate the Caliph from the ruling regime in Turkey (Cleveland 2004: 160-161).

Indian Muslims condemned Husain's treacherous actions and the spiritual leader of the Ali brothers, Abdul Bari, considered Husain and those associated with him as enemies of Islam (Qureshi 1999: 83). The Muslim League also condemned his behavior because he risked the safety and integrity of Mecca. Husain's actions jeopardized not just the Muslim holy city of Mecca, but the territorial integrity of the Ottoman Empire. Within a few years, World War I ended and the political capitol of the Islamic world, Istanbul, was occupied with the assistance of British forces. The occupation was a fitting ending for decades of territorial retreat in Ottoman territories. Despite this history, "The Ottoman Empire never lost land from 1878 to 1908” (Ardic 2009: 64-65).

Muhammad Iqbal, one of the most prominent Muslim philosophers in India, lamented this unfortunate turn in his 1909 work Shikwa (Complaint), and his 1913 follow up 'wa jawab I Shikwa' (Response to Complaint). "Why no more are worldly riches and wealth amongst Muslims found...Others have taken over the World, and our days are by gone and done" (Iqbal 1998: 34, 36). Iqbal also bemoaned the amount of internal dissension that prevented Islam from moving beyond its current morass. "There are sects all over, and castes are some where. In these times, are these ways, to progress and to prosper?...The reverends are immature, no substance in what they preach, no lightning is in their minds, no fire is in their speech" (Ibid: 92, 96).

Exacerbating tension in India even further was the 1918 Montagu-Chelmsford report by the British government which eschewed the ideas of the Lucknow Pact and 
threatened "the preservation of Muslim rights and privileges" (Qureshi 1999: 91). Muslims represented only $27 \%$ of the population in India (Ibid: 4), and they had now witnessed their strongest representative occupied abroad and their prospects dimmed at home. According to British archives, circulating around this time period were posters "declaring the existence of an organized conspiracy to destroy Islam" (Hasrat and Pernau 2005: 3). The origins of the Khilafat movement evolved out of this environment and materialized in a December 1918 meeting of the Muslim League.

Significantly, this was the first time leading 'ulama took part "in an overtly political organization" like the Muslim League (Minault 1982: 60). They called on the government to withdraw all forces from the various Islamic holy areas like the Hijaz, Damascus, Najaf and Karbala (Ibid: 61). The most important provision on the Muslim side concerned the fate of those outside their borders. The chairman of the welcoming committee stated that, "Having regard to the fact that the Indian Musalmans take a deep interest in the fate of their co-religionists outside India, and that the collapse of the Muslim Powers of the world is bound to have an adverse influence on the political importance of the Musalmans in the country and...have a far-reaching effect on the minds of even the loyal Musalmans of India" (Qureshi 1999: 98).

Despite the attendance of the 'ulama and firebrand speeches against the British government, the Muslim League did not serve as the locus of political mobilization. Many were wary of the Muslim League's loyalty to British rule, which was one of its founding principles in 1906. Furthermore, the league itself had decayed to less than 800 members and was not a purely religious organization (Minault 1982: 72-73). Therefore, 
two organizations, both rejecting the Muslim League's claim to represent Muslims, emerged in the spring of 1919 (Ibid: 250). The All-India Khilafat Committee was led by the Ali brothers, whose longstanding and peaceful defiance of the British endeared them to many, and Abdul Bari, a religious leader and avid supporter of Turkey. Its first meeting in Bombay called for branches to be organized throughout India "to hold meetings constantly in order to keep Muslims informed on the Khilafat problem" (Ibid: 74).

The second group was the Jamiat al 'Ulama e-Hind, organized by Abdul Bari but nominally led by several other religious figures, which was a mixture of different religious schools. The 'Ulama did not think of themselves as political revolutionaries, but religious leaders protecting Islam from foreign aggression and internal decay. As a consequence of its heterogeneity, wide scale consensus was hard to reach even on the most general of matters. At the first meeting, when Abdul Bari issued a fatwa attempting to delineate the holy places and protect the Caliph, many objected believing it was against sharia' or hostile to the British government (Minault 1982: 80). Though by the end of the year, the 'Ulama congealed enough to join those calling for a defense of the Caliphate and side with their Hindu brethren.

By the end of 1919, the INC, Muslim League, All-India Khilafat Committee and the Jamiat al Ulama joined together in boycotting the peace celebrations of World War I. In early 1920, the Khilafat conference resulted in 'The Constitution of the Indian Khilafat Conference' which outlined three objectives; maintain the power and authority of the Caliphate, any decision regarding the Islamic holy places will be in accordance with 
sharia', and striving for the attainment of swaraj in India. To pursue these objectives the constitution stated in part that they will establish relations with Muslims in foreign countries and remove mutual conflicts among them, make the Khilafat movement a success in India and abroad, and promote understanding of unity with non-Muslims in India (Qureshi 1999: 425).

By 1920 two methods of petitioning the British government were active. The first involved sending delegations to local and federal British authorities. Muhammad Ali led a deputation to London which spanned the course of the year. ${ }^{8}$ However, this was an old practice that largely proved ineffective and led to the adoption of noncooperation as a negotiating tool. The failure of the London delegation to prevent the partitioning of the Ottoman Empire intensified the anguish of Indian Muslims and their willingness to embrace new methods.

In the midst of planning the first phases of noncooperation, the decision of over 60,000 Indian Muslims to migrate to Afghanistan disrupted the unity of effort behind the Khilafat movement. Sunni Islamic legal theory divides the world between dar al-Islam (a country under Islamic rule) or dar al-Harb (a land of war, country not under Islamic rule). The solution to Muslims living in dar al-Harb was jihad or hijra (migration) (Qureshi 1999: 42). There had been many calls in colonial India's history for hijra, but the impetus in 1920 came via three ways. First, the aforementioned failure of the London delegation and publication of the partitioning of Arab lands/Islamic holy places outside

\footnotetext{
${ }^{8}$ Ali's delegation in London is an important aspect of the Khilafat movement and is discussed at length in A.C. Niemeijer's The Khilafat Movement in India, 1919-1924. From my study its impact on domestic mobilization in India was negligible because of its failure and more novel developments within India. As a result the delegation's work will be left untreated.
} 
the Ottoman Empire devastated not just the prospects of the Caliphate remaining but of Britain's complicity in its destruction. Secondly, the new Amir of Afghanistan in an attempt to strengthen his political hand against the British, welcomed all Indian Muslims who wished to migrate (Ibid: 45). Lastly, the absence of a sole authoritative voice of Islam in India coupled with the multiplicity of schools of thought left space for certain 'ulama to state that hijra was a religious duty.

As was the case for this unique juncture in India's history, no religious position was left uncontested. The Ali brothers, who made a case for hijra in a letter to a British official in 1919, were at odds with their religious mentor and leading Sufi authority Abdul Bari (Ibid: 47). ${ }^{9}$ Many of the deoband leaders also disagreed with a fatwa calling for hijra, as did Hasrat Mohani, Ali Jinnah and Muhammad Iqbal. Despite the general rejection for hijra on the belief it would weaken the cause in India, tens of thousands migrated because "They understood from the imams and pirs of their local mosques and shrines that Islam was in danger, and one of the best ways to save their souls was to migrate to a country where their faith was not imperiled" (Minault 1982: 106). Afghanistan was not prepared for such an effusive response and after several months asked many to return home and nearly $75 \%$ did just that. The Khilafat recognized the power of the religious networks behind the hijra, many who preached to the illiterate and uneducated, and gave them a subcommittee position in the Khilafat committee (Ibid: 107).

\footnotetext{
${ }^{9}$ There is differing interpretation on Abdul Bari's position. Qureshi emphatically states that based on a misrepresentation of a telegram, and Bari's later clarification in a local newspaper, that Bari found hijra commendable but not mandatory. Additionally, other religious leaders wanted to know why he was against hijra (Qureshi pg. 48). Minault however states that Bari issued a fatwa in favor of the migration (pg. 106). An explanation for this disparity may be that Bari qualified his support for hijra, but any measure of support was magnified beyond its intent making public interpretation reality.
} 
The framework for noncooperation was established in a series of provincial Khilafat conferences. A joint meeting of Hindu and Muslim leaders announced a four stage program of noncooperation, with each phase enacted only after consultation and preparation (Minault 1982: 98). What worried Gandhi and many of his Hindu confederates was the visceral rhetoric of certain Muslim leaders that did not conform to the spirit of noncooperation. ${ }^{10}$ Implicit in this agreement to noncooperation was nonviolence.

The mutual commitment to nonviolence tested the integrity of the Khilafat movement. Various interpretations of this strategy revealed schisms among Muslim denominations and political leaders. Part of the Khilafat leadership led by Hasrat Mohani "permitted the use of violence against the enemy where necessary" (Prasad 2000: 162). Throughout this new stage of the Khilafat's life a "struggle was going on between the militant Muslims and Gandhi over the new political technique of noncooperation" (Minault 1982: 91). Because of these inter-communal differences, personal relationships were instrumental in maintaining cohesiveness.

Of all the Muslims in India, Gandhi depended on and communicated most with the Ali brothers and Abdul Bari for their understanding and partnership in peaceful disobedience to the British government. Gandhi often exchanged letters with Muhammad Ali, as both were intermittently imprisoned in different parts of the country. Gandhi's communiques were not perfunctory business memorandums but oftentimes heartfelt concerns about the welfare of others, and worry about the growing divide

\footnotetext{
${ }^{10}$ British sources in Delhi seemed particularly sensitive to this fact, Hasan and Pernau 2005: 27.
} 
between the Hindu and Muslim communities. While Gandhi may have used the Caliphate issue to build a strong opposition to British rule, he genuinely believed in its merits. "As time progressed I found that the Muslim demand about the Khilafat was not only not against any ethical principle, but that the British Prime Minister had admitted the justice of the Muslim demand" (Gandhi 1949: 368). In turn, the British aware of the important friendship between Gandhi and the Ali brothers, attempted to create a rift among them and the Hindu community. The accusation was that "the Ali brothers wanted Afghanistan to invade India and desired a Muslim rule in the Subcontinent" (Qureshi 1999: 284).

The early stages of noncooperation were successful in a variety of domains. Aligarh college, the bastion of Muslim education in India and strongly aligned with the British government saw over 150 students pledge to walk out, and the administration was forced to close the school for a month (Minault 1982: 117). Enrollments for High Schools in the Central Provinces dropped to half for many, and in one instance "only 150 students [were] on the roll against nearly 600 at the beginning of January [1921]" (Hasan and Pernau 2005: 93). Economically, the movement succeeded in promoting a boycott of foreign products, and large amounts of money were donated throughout the country. Additionally, many Khilafat volunteers voluntarily went to jail and businesses shut their doors in solidarity with those who sought to protect the Caliphate (Minault 1982: 167).

The 'ulama encouraged lay Muslims to support the Khilafat by emphasizing salvation contingent on noncooperation against British authority. The status of the Caliphate in Istanbul was inextricably linked, religious leaders said, with the safety of 
Islam and the promise of heaven. Shaukat Ali and Abdul Kalam Azad issued a notice that stated "whoever wavered an inch from the obligation of Islam and from allegiance to the Khalifa and died in that condition would die the death of an infidel" (Hasan and Pernau 2005: 61). Similarly, the struggle was not just maintaining the Caliphate, but fighting against those who wished to destroy it. In an April 1920 Khilafat conference, Azad Subhani "threatened with hell fire any Muslim who remained faithful to English rule if the Khilafat problem was decided against Muslim wishes" (Ibid: 65). The leader of the Jamiat e Ulama, Abdul Bari, echoed this sentiment by declaring "anyone who cooperated with the British infidels was an infidel himself” (Minault 1982: 121).

\section{2: The Decline of the Khilafat Struggle}

While this fiery rhetoric from the 'ulama concerned Gandhi, the movement maintained momentum and he was ready to call for civil disobedience in what was later called the Bardoli resolution. Despite its strong start, the early successes of noncooperation were not a bellwether for things to come. On the contrary, the accomplishments of the Khilafat program were front loaded. A breakdown of authority and unity led to a situation of enmity between both Hindu and Muslim, and the complete degradation of the political movement entirely.

At the outset, many students agreed to withdraw from government sponsored universities. This fervor waned and many returned as they realized their livelihoods 
depended on a reputable education. British records at the time state "there was a marked tendency for the better type of students to stay and for the inferior to leave" (Hasan and Pernau 2005: 93).

Further complicating efforts, reports of bad bookkeeping and corruption rattled multiple Khilafat bodies throughout India. Indian Muslims expended considerable effort in closing shops, boycotting foreign goods, and sacrificing their livelihood for the sake of the Khilafat movement. Acrimony against the organization was natural when it was revealed that "Money deposited with the treasurer had never been banked; no budgets were ever prepared... [and] travel had been by first or second class, almost never third" (Minault 1982: 189).

The loss of participants in the noncooperation movement and embezzlement significantly affected the vitality of the Khilafat cause. Yet nothing damaged the integrity and unity of the Khilafat movement more than the widespread riots and communal violence soon after the initiative was launched. These actions undermined not just the promises and faith the public entrusted in the Ali brothers and Gandhi, but the prospects of Muslims and Hindu cooperating peacefully in a national project. It was not just the ferocity of the riots but the timing that betrayed the cause of Muslim-Hindu coexistence. Violence between the two communities was not new, but its escalation in a period of intense cooperation and attempted détente made further rapprochement untenable. "Not that there were no riots prior to 1920, but they were few and far between. The communal riots prior to 1920 paled into insignificance when compared to the riots in 1920's and 1930's" (Karandikar 1969: 177). 
Gandhi was aware of the fraying trust between the two communities and wrote to an influential Muslim leader in 1922 that, "Hence, am I anxious and impatient to persuade my countrymen to feel non-violent not out of our weakness but out of our strength. But you and I know that we have not yet evolved the non-violence of the strong and we have not done so because the Hindu-Muslim union has not gone much beyond the stage of policy. There is still too much mutual distrust and consequent fear" (Gandhi 1967: 89).

The first large scale violent act during the Khilafat movement is known as the 'Mappilla Rebellion' in August 1921. After a mosque was searched by a detachment of police, a rumor spread that it had possibly been destroyed. A mob of reportedly over 3,000 spread throughout the city of Malabar which "cut telegraph wires, and burned post offices and police stations...proceeded to rape, murder, loot and burn” (Minault 1982: 147). Hindu temples were also destroyed in the violence and martial law was declared for over six months. The British placed the blame for the rebellion on the Khilafatists, and even a British "champion of the Muslim separatism, considered the Moplah atrocities as the direct sequel to the appeals of racial hatred generated during Khilafat agitation" (Karandikar 1969: 177). The event was reported widely throughout India, and the "traditional Hindu stereotype of a Muslim as particularly prone to be fanatical, aggressive and violent now acquired a new shine" (Prasad 2000: 166). Exacerbating relations with their Hindu neighbors, some Muslim leaders attempted to justify the actions of the Muslims in Malabar because the Hindus "not only do not help them [Moplahs] or observe neutrality, but aid and assist the English in every possible way" (Ibid: 167). 
The second major incident came after the Prince of Wales visited Bombay near the end of 1921. Peaceful boycotts of his visit were held throughout India except in the city he visited. Fires were ignited, shops ransacked and "Most unfortunately, the rioting also had communal overtones. Christians, Parsis, and Anglo-Indians, identified as progovernment, were singled out for attack" (Minault 1982: 177). In response, the British jailed major leaders throughout the country. The guiding force of the movement was decimated and along with it prospects of its continued relevance in society. "The disorganized state of affairs following the arrest of some prominent leaders and the increasing squabbles among those still free...had obviated any possibility of rejuvenating the waning agitation" (Qureshi 1999: 362).

Gandhi firmly believed that "those who wanted to lead the people to Satyagraha ${ }^{I I}$ ought to be able to keep the people within the limited non-violence expected of them" (Gandhi 1949: 391). The religious environment of India made this a herculean task. Muslim leaders were unable to rally behind the concept of nonviolence and encourage their followers to do the same. Muslims around India reflected this division as some regions remained peaceful, and others sporadically broke out in violence. Additionally, the temperament of many Muslim leaders varied from Gandhi and the Hindu community. Peaceful sit-ins and fasts from Gandhi and his followers contrasted strongly with the fiery rhetoric of the Jamiat e Hindi who warned their fellow believers to follow their example or risk losing their place in paradise.

\footnotetext{
${ }^{11}$ Translated as life force or soul force, its usage generally meant non-violent resistance
} 


\section{3: Reaction to the abolishment}

Atatürk's decision to remove the Caliphate sent shock waves throughout India and the Islamic world. "Through the field reports gathered by British officials regarding the situation in each of the Indian provinces after the Ottoman Caliphate's abolition, a picture of overall shock, resentment, and condemnation vividly emerges" (Hassan 2009: 76). British accounts from Delhi tell a similar story, "News of the deposition of Abdul Majid and the abolition of the Khilafat was received by the Delhi Muslims with sullenness, and the action of the Turks was generally condemned although the feeling of resentment was not outwardly shown" (Hasan and Pernau 2005: 51). At a Khilafat conference in Calcutta, Muhammad Ali stated that, "When the Treaty of Lausanne was signed, he [Atatürk] said, two things remained for us to do. One was the restoration of the Jazirat-ul-Arab...And the other was the re-establishment of the Khilafat itself on a firm democratic basis...It may seem that we are more Arab than the Arabs and more Turkish than the Turks, but it will be apparent that all we are is Moslems. As Moslems we cannot countenance a section of the Turkish nation disconnecting its national Government from the Khilafat.” (Ibid: 215-216)

Ali's statement is full of irony. Both he and Atatürk utilized the Caliphate as a symbol for a new national project. For Ali and other ranking members of the Khilafat movement, the continuation of the Caliphate in Turkey validated the existence of a movement that grew disproportionate in influence to its demographic in India. Simultaneously, it unified differing factions of society while also challenging British 
hegemony. Atatürk used the Caliphate as a cultural artifact to bolster his burgeoning movement in Ankara and gain the support of Muslims throughout the country. Once his grasp on power was complete, he rid himself of the only institution and affiliated parties that could challenge the new Republic.

The fact that the Caliphate was removed not just by a fellow Muslim, but a venerated and militarily successful one, was perhaps the greatest shock. Despite his action, Atatürk was so venerated the Indian Muslim delegation in Britain proposed that Mustafa Kemal assume the position himself (Hassan 2009: 78). Muslims in India were quick to bemoan lesser transgressions by the British but betrayal by someone close put them in a guarded position. The Khilafat strategy depended on representing Western policies as inimical to Islam. Western goods were boycotted and anti-British demonstrations were popular, but what is the recourse when the iconic defender of the faith is the one who contributes most greatly to its destruction?

Several high ranking Muslim leaders discussed this and "They decided that it was not advisable to condemn the Turks for the deposition of the Caliph and they should await further particulars from the Angora National Assembly. It was pointed out that by their support of the Turkish cause they had incurred the displeasure of the British Government, and if they now turn against the Turks they would make themselves a laughing stock before the world" (Hasan and Pernau 2005: 51-52).

While some were critical, albeit quietly of Atatürk's deed, Muhammad Iqbal believed a different trend was at work. For Iqbal, "the last five hundred years religious thought in Islam has been practically stationary... [it] is [with] the enormous rapidity 
with which the world of Islam is spiritually moving towards the West” (Iqbal 1962: 7).

Turkey, however, was an exception. Iqbal conceived ijtihad [independent reasoning] was the principle of movement in the structure of Islam, and saw it at work in the new Republic. "Passing on to Turkey, we find that the idea of ijtihad, reinforced and broadened by modern philosophical ideas, has long been working in the religious and political thought of the Turkish nation...If the renaissance of Islam is a fact, and I believe it is a fact, we too one day, like the Turks, will have to re-evaluate our intellectual inheritance" (Ibid: 153).

Thus, Iqbal was not critical of the Grand National Assembly in Turkey but supportive of it. He believed the reinterpretation of Islamic law is vital to its efficacy in society, even if undoing historical norms. Iqbal answers the question whether the Caliphate should be vested in one person;

“Turkey's ijtihad is that according to the spirit of Islam the Caliphate or Imamate can be vested in a body of persons, or an elected Assembly...Personally I believe the Turkish view is perfectly sound. It is hardly necessary to argue this point. The republican form of government is not only thoroughly consistent with the spirit of Islam, but also has become a necessity in view of the new forces that are set free in the world of Islam" (Ibid: 157). 


\section{4: After the Caliphate}

The abolition of the Caliphate was the death knoll for an organization determined to ensure the institution's existence. Thereafter, immediate energies were directed at aligning the movement with the new Muslim Congresses and self-appointed Caliphs like King Hussain of the Hijaz (Minault 1982: 206). Khilafat conferences were held after 1924 though "they were no better than lifeless annual rituals" (Qureshi 1999: 409). Additionally, any remaining goodwill with the Hindu community was lost in the Kohat riots in the fall of 1924. The propagation of an anti-Islamic polemic led not just to violence but a permanent falling out between Gandhi and the Ali brothers (Ibid: 395). A relationship which symbolized the unity between Hindu and Muslim was gone, as was any hope of rapprochement between the two communities.

Though the Khilafat movement ultimately failed, it succeeded in generating political networks throughout India. The expansion of the movement throughout India led to groundbreaking cross-cultural interaction. Unfortunately for the movement, it reinforced prior convictions and stereotypes of the other. But in so doing, it created new space for political and religious movements to foment in a wave of territorial nationalism. Most of these leaders did not benefit from a charged political atmosphere or on the heels of a world war remaking half the globe. Instead, grievances and organization were more local and specific. The ground was prepared with the "provincialization of politics" by the British between the two world wars (Talbot 2000: 134). It aroused the involvement of 'ulama in political activities that heretofore had never existed. The Khilafat movement 
created a platform where the involvement of activist 'ulama would only grow in time. A key difference between themselves and the nationalist movement of the Ali brothers, was that "their emphasis remained the religious guidance of Muslims, and the promotion of their solidarity and self-consciousness as a community" (Minault 1982: 123). The inability of the Khilafat movement to foster a climate of coexistence between the Hindu and Muslim communities made the distance between the two communities greater than it had ever been in recent past.

For many Hindus, the development of the Khilafat movement only lit the fire of Islamic nationalism. Gandhi, summarizing the sentiment of his fellow Hindus stated "You asked the Hindus to make common cause with the Mussalmans on the Khilafat question. Your being identified with it gave it an importance it would never have otherwise received. It unified and awakened the Mussalmans...[N]ow that the Khilafat question is over, the awakened Mussalmans have proclaimed a kind of Jehad against us" (Prasad 2000: 189).

Soon after the Caliphate was abolished, and in the wake of heightened MuslimHindu communal strain, the former President of the INC in Calcutta Lala Lajpat Rai made some revealing remarks. In December 1924 he wrote a letter that succinctly captured not just the political reality of the time but presciently notices the seeds of an Islamic nation. While Muslim leaders pushed for separate electorates in the provinces and claimed to fight for a united India, Lajpat Rai saw this as achieving the opposite end. "Jinnah is the latest recruit to this party, and I really cannot understand how he calls himself a nationalist still” (Ibid: 438). For Rai, "this plan provides for a complete 
division of India, as it is, into two sections: a Muslim India and a non-Muslim India." Despite his own admonition, Rai suggests in order to avoid "trampling on the sensitiveness of the Hindus and the Sikhs" a partition of India with four Muslim states. "But it should be distinctly understood that this is not a united India. It means a clear partition of India into a Muslim India and a non-Muslim India." Another contemporary noted a few years later in his book 'The Future of Islam' that Hindu Muslim unity was impossible, and that "Hindus and Muslims were two separate nations" and the only reasonable goal was the conquest of India for Islam (Karandikar 1969: 255).

There was a firm realization immediately after the fall of the Caliphate, and the failed experiment of Hindu-Muslim cooperation embodied in the Khilafat movement, the inevitability of a Muslim nation. Mukhtar Ahmad Ansari, an influential Muslim and former president of the INC, spoke about the state of affairs in his presidential address in 1927:

"While attempting to solve the Hindu-Muslim question we should not, however, mistake the symptom for the disease. The political and religious differences, which are straining the relations between the two communities are but outward manifestations of a deeper conflict, not peculiar to India or unknown to history. It is essentially a problem of two different cultures, each with its own outlook on life, coming in close contact with one another" (Karandikar 1969: 181).

A response to this widespread enmity was the creation of new political bodies designed to safeguard their respective identities. In 1928, Ansari formed "the first 
nationalist Muslim organization called the Nationalist Muslim Party” (Ibid: 182).

Muslim organizations were formed based on provincial realities and the failures of past political efforts. In the Punjab, the Majlis-i-Ahrar-Islam was formed in 1929 "with the avowed aim of establishing an Islamic state in the sub-continent and its membership came from the cadres that had lost hope in the League, Khilafatists and the Congress" (Malik 1995: 319). It was not merely political realities, but communal rioting and "the form of murderous attacks by individuals belonging to one community against those of the other. Some of the most serious incidents of this nature took place in the Punjab in (sic) 1927”(Prasad 2000: 258).

The partition of India did not occur for another twenty years, but its foundation lay in the remnants of the Khilafat movement and the mobilization of Muslims in various parties throughout India. While the threat to the Caliphate united and mobilized thousands of Muslims and Hindus, It became increasingly clear in the midst of communal violence, failed political projects and competing visions that the prospect of a united India was untenable. Multiple political parties rose in the wake of the Khilafat movement and contributed to a localized consciousness as a Muslim nation. These parties eventually faded away as the Muslim League gained notoriety as a "supra-regional Muslim party" and the road to the two nation concept was established (Malik 1995: 321)

The threat to the caliphate's future prospects was sufficient cause to create a mass political movement that transcended historical religious and cultural boundaries. Decades of colonial rule and failed political prospects preceded this movement and provided added momentum that otherwise would have been nonexistent. The experiment 
of the Khilafat movement was short lived, serving only as a reminder of the religious and cultural differences while reinforcing negative stereotypes of the other. Within a year of the caliphate's fall in Turkey, both Muslim and Hindu leaders recognized the distinct differences in their respective societies. At this point the idea of two separate nations rather than a united India seemed not only more tenable, but realistic and practical. 


\section{CHAPTER 5}

\section{EGYPT}

5.0: Egypt's introduction to Western Imperialism

Egypt, arguably more than any country in the Islamic world, has a unique history of Islamic rule intertwined with western and colonial domination. The Abbasid Caliphate reigned in modern day Iraq from 750 to 1258 . During this period, the Abbasids created an army composed of converted Circassian children loyal to the Caliphate (Goldschmidt 2004: 10). These soldiers, referred to as Mamluks, were a military caste that served as an extension of Abbasid power until the Mongols devastated Baghdad. The Caliphate was then transferred to Egypt, where it lasted until the Ottomans took power in 1517. For nearly three hundred years the Ottomans ruled Egypt despite domestic uprisings. Napoleon invaded Egypt in 1798 and ruled for a short time until he was expelled by Turkish forces. A young officer named Muhammad Ali emerged as Egypt's first modern ruler, effectively managing a separate province in the Ottoman Empire. He rapidly modernized the country through economic and political reforms, and invited European experts to assist in the country's development. Ali's achievements in Egyptian society constitute in the words of the eminent historian Philip Hitti, "the first attempt at nationalization in the Arab world" (Hitti 1970: 722).

Egypt's semi-autonomous status did not last long. The 1838 Anglo-Ottoman treaty left Egypt's nascent industries open to foreign domination (Goldschmidt 2004: 26). The scions of the Ali dynasty continued the modernization program of their forefathers 
but mismanaged certain aspects of the government's financial sector that allowed disproportionate foreign control of Egypt's land and industry. This crisis came to the fore under Khedive Ismail whose excessive borrowing and poor financing led to state default and dual control by England and France in 1879 (Hitti 1970: 750). The poor financial situation led to dire straits for the common Egyptian as well as government services. A nationalist revolt led by Ahmad Urabi sought to establish a new constitution and representative government, but a firm British response led to the exile of Urabi and British occupation. Nominally, the land retained its Ottoman status during British rule, but the advent of World War I and Turkish involvement caused England to declare a protectorate over Egypt (Ibid).

\section{1: Egypt's New Nationalist Roots}

A majority of Egyptians felt sympathy for the Ottomans during World War I, but failed to deliver any aid other than moral support. ${ }^{12}$ One significant cause lies in the strict security imposed on Egypt after Britain declared it a protectorate (Gershoni and Jankowski 1987: 25). Even so, the outbreak of hostilities failed to generate any significant religious mobilization. British sources at the time state that "the religious issue....remained dormant" (Ibid).

\footnotetext{
${ }^{12}$ Some of the literature is contradictory on the degree of support for the Ottomans during the Great War. Gershoni mentions that "In spite of the prevalent pro-Ottomanism of Egyptian popular opinion during World War I" (Gershoni and Jankowski 1987: 33), while Goldschmidt states, "Indeed, the Egyptian people, except for the exiled Nationalists, had shown few signs of restiveness or pro-Turkish sentiment during the war" (Goldschmidt 2004: 67).
} 
In fact, the lack of sentiment continued even after the fall of the Ottoman Empire and occupation of Istanbul. The Watani Party, a Pro-Ottoman party from 1910-1915 before being disbanded, in 1919 reversed course. The official position during the Paris peace conference was that "the Ottoman claim to sovereignty over Egypt had been nullified by wartime developments" (Ibid: 45). At this point in Egypt's history, all of the country's main political bodies, the Wafd, Watani Party, and Liberal Constitutionalist Party, adopted programs based on nationalist self-determination, not Islam or religious solidarity with other Muslim communities. In fact the political party which would dominate Egypt's early independence period, the Wafd, embraced the Christian Coptic community. Some of the early leaders were Copts, and during the drafting of the 1923 constitution Copts refused separate electorates but called for a unified election representing all Egyptians. Moreover, the Christian minority served and suffered along with other leaders of the Wafd. Two were deported with other leaders in 1921 and four of the seven leaders condemned to death that same year were Coptic (Ibid, 43).

The Wafd party derived its name from a gathering of notable politicians in 1918 who were preparing to send a delegation (wafd) led by Sa'ad Zaghlul to the Paris peace conference. When this request was sent to London, the British categorically refused and even chided the Egyptian administrator, Reginald Wingate, for receiving the delegation himself (Kedourie 1970: 96). For Zaghlul, this was not only an affront to his vision of an independent Egypt, but a betrayal of years of service and cooperation with colonial authorities. Lord Cromer, the previous administrator known for his firm rule remarked that he only knew Zaghlul a short time but for whom "I have learned to entertain a high regard". Within a few months, one of "the most able of the co-operators became the 
strongest opponent of the British and the most determined and unyielding advocate of the complete independence of Egypt" (Adams 1968: 229). Zaghlul's exile to Malta ignited protests and demonstrations throughout Egypt causing widespread damage. To appease the populace, Zaghlul was released and allowed to air his grievances in France. In a cruel twist of fate, the day he arrived coincided with American recognition of the British protectorate over Egypt, breaking not only the promise held in Woodrow Wilson's call for self-determination, but dashing the prospects for any agreement in Paris (Goldschmidt 2004: 70).

The episode with Zaghlul was emblematic of an overstretched empire making poor decisions based on misperceptions of local dynamics. World War I greatly depleted the treasury and manpower of the British Empire. This resulted in lower standards of recruitment for the foreign service and the Army. Soldiers, poorly trained and educated about local customs, "frequently scandalized the population and contrasted strongly with the decorum which Egyptians had been accustomed to associate with Englishmen..." (Kedourie 1970: 103). Additionally, the Suez Canal was Britain's prized possession in the region and they zealously protected it.

From 1919-1923, Egyptians led by Zaghlul and the Wafd negotiated multiple agreements to finalize the status of Egypt's political future. Whenever the British seemed close to an agreement, Zaghlul would defer to the Egyptian people who demanded more concessions. This would play out over many months resulting in Zaghlul being exiled two times (Ibid: 159). Eventually in 1922, an agreement was reached where Sultan Fu'ad transitioned as King, and the government transitioned to a parliamentary system. 
In 1923, a committee comprised of scholars sympathetic to British interests drafted a constitution. The final document endowed the monarchy with excessive powers, designed to contain mass popular movements and the power of the Wafd (Botman 1998: 286). Furthermore, four points were reserved by the British until both sides could arrive to an amicable accommodation. ${ }^{13}$ These issues "robbed Egypt of anything more than a de jure independence, for they allowed the British influence on the Egyptian government... and enabled Britain to use the reserved points as a lever for intervention" (Sayyid-Marsot 1977: 63). Zaghlul and his other ministers returned from exile and participated in the January 1924 elections. The Wafd won ninety percent of the vote and Zaghlul was appointed prime minister in March.

5.2: Removal of the caliphate and the conservative reaction

These achievements in political independence, albeit limited by the aforementioned reservations, coincided with the removal of the Caliphate in Istanbul. Like their contemporaries in India, many Muslims in Egypt believed Atatürk would free them from colonial rule. Traditional religious circles believed he would liberate Egypt and thus make it "unnecessary to worry about the election of a Parliament, or about the return of Zaghlul, as Kemal will redeem his promise [sic] to bring Zaghlul back himself" (Gershoni and Jankowski 1986: 47). The constitution of 1923 and subsequent elections

\footnotetext{
${ }^{13}$ The four points were the security of the communications of the British Empire, defense of Egypt against foreign aggression, protection of foreign interests and minorities, and the status of Sudan
} 
severely curtailed the role and influence of religious leaders. However, they hoped this would be a fleeting moment in Islamic history and instead open the door for a strong political and military leader like Atatürk to revitalize the 'umma. Rather, Atatürk's action was viewed as a betrayal and "the most repugnant crime against Islam in the history of Islam" (Ibid: 56).

Al-Azhar, the oldest and most renowned institution of learning in the Islamic world, underwent significant changes and reforms from the late $19^{\text {th }}$ to early $20^{\text {th }}$ century under the venerable guidance of Muhammad Abduh. ${ }^{14}$ Widely regarded as one of the founding fathers of Islamic modernism, Abduh was not able to radically alter the traditional position of Al-Azhar which "has always exerted in the direction of maintaining the traditions of the past unbroken" (Adams 1968: 207). A statement by the Sheikh of Al-Azhar "I repudiate the action of the Kemalists in its entirety" embodied the feeling of conservative Muslims and the institution of Al-Azhar (Hassan 2009: 75). Within a few weeks Al-Azhar, along with other leading 'ulama and the Chief Mufti of Egypt, published a decision "concerning the convening of an Islamic Congress for the Appointment of a new Caliph" (Toynbee 1927: 576).

The religious leaders of Egypt presented the legal basis for the Caliphate and its necessity for Muslims worldwide. "The post of Caliph possesses a paramount importance inasmuch as the Caliphate is responsible for maintaining the prestige of the religion and its adherents, for preserving the unity of the Islamic Community, and for

\footnotetext{
${ }^{14}$ More can certainly be said about Abduh's impact on the life of lay Muslims and those that would eventually rise to political power in colonial Egypt. Hourani chronicles Abduh's impact on Al-Azhar in his work Arabic Thought in the Liberal Age: 1798-1939. Despite his unprecedented accomplishments in reforming Islamic thought, "[H]is ideas provided a better basis for apologetics and polemics than for social reform and cultural rebirth" (Kerr 1966: 105).
} 
creating strong and solid links between its members". This decision acknowledged that "the emotion aroused by the action of the Turks in abolishing the office of the Caliphate... has thrown the Islamic World into such an agitation that it will be impossible for Muslims to discuss this organization, and to form a considered opinion regarding it..." Thus, the leaders called for an Islamic congress to be held in one year "to which the representatives of all the Islamic peoples shall be invited, in order to consider upon whose shoulders the Islamic Caliphate ought to be placed." This gathering would later be postponed until 1926.

Another critical component of the Egyptian religious community was Rashid Rida. Interpreted as Abduh's main religious disciple, Rida began to take a visible role internationally in calling for a sustained Caliphate to safeguard Islamic heritage and unity. If Abduh provided the ideological infrastructure to reform a Muslim's daily life and transform Islamic societal institutions, Rida sought to create a superstructure to encapsulate these ideas. The first phase took place as others were rebelling against Ottoman rule. Rida did not see the circumstances sufficiently justifiable to call for the dismissal of the Caliphate as noted below:

"Muslims all over the world believe that the Ottoman state is fulfilling the role of defender of the Muslim faith. It may fall short in serving Islam because of the despotism of some of its sultans, or the irreligion of some of its pashas, or the threats from Europe. But these are symptoms that will disappear when their causes cease, as long as the [Ottoman] state remains independent and responsible for the office of the Caliphate" (Haddad 1997: 261).

Despite the disparaging comments about the Ottoman's religious shortcomings, Rida identified two issues; the lack of education, and the need for Ottoman protection. 
"In fact, he never advocated the formulation of an Arab caliphate to rival the Ottoman one before World War I" (Ibid). He actually appealed for rapprochement between Arabs and Turks. "Islam both gave people equal rights and transformed them into brethren. The achievements of each should be perceived as complimentary. Otherwise, racial conflict which was the cause of Muslim weakness in the past might become the cause of their total destruction in the future" (Ibid).

The second phase of Rida's attitudes toward the caliphate occurred during World War I. He continued to be a loyal Ottoman subject, but began to direct his appeals towards Europe. Already a well-known figure in the Middle East at that time he furthered his reputation by making an impression on some of Britain's most powerful leaders. Rida took it upon himself to become the self-appointed representative when he wrote in a memorandum to Britain:

"What I seek from Great Britain represents the feelings of Mohammedans in general and Arabs in particular. They all wish Great Britain to use her influence to retain the complete independence of Islam in its cradle in the Arabian Peninsula and the bordering Arabian countries...In doing this Great Britain will gain the friendship and loyalty of more than one hundred million of her Mohammedan subjects...” (Ibid)

The final phase of Rida's efforts to establish the Caliphate occurred after the conclusion of World War I. His thought changed from maintaining the Caliphate to reviving a new, more righteous and just one. His main treatise on this issue, al-Khilafa aw al-imama al-'uzma ${ }^{15}$, was written a year before the Caliphate was abolished by Mustafa Kemal Atatürk, founder of the modern Turkish nation. Al-Khilafa would outline

\footnotetext{
15 The Caliphate or the Grand Imamate
} 
his vision for the future Caliphate and set forth his argument that it remained a vital part in the Islamic community. In it he describes the Caliphate's importance and composition, and the necessary steps to implement it in the modern world.

Rida cites traditional jurists and historical precedent for the importance and necessity of a caliphate in Islam. Additionally, he cites traditions and the attributed sayings of Muhammad in the Hadith. He uses a saying by Muhammad, "Whoever dies without having given bay' $a^{16}$ dies the death of the days of jahiliyya ${ }^{17}$ " to support his argument that Muslims need a form of established government (Haddad 1997: 273). But most noticeably, and ironically, he fails to reference any verse in the Qur'an to support his argument (Kerr 1966: 159).

He distinguishes between three different types of Caliphates; the ideal or true Caliphate of the rashidun ${ }^{18}$, and the subsequent Caliphates of necessity and tyranny (Inayat 1982: 71). Rida validates the existence of the latter for the sake of unity in the community, but he qualifies this statement by stating that it must be overthrown when possible (Haddad 1997: 274). This action would be under the auspices of the ahl al-hall wa'l- 'aqd ${ }^{19}$ (Inayat 1982: 72).

The last challenge was determining the proper location for the Caliphate and possible candidates as Caliph. Rida acknowledges several possibilities, like Sharif

\footnotetext{
${ }^{16}$ Allegiance or an oath to a ruler, Rida perceives it, as Haddad mentions "to the imam of his time".

${ }^{17}$ Literally meaning the 'days or period of ignorance' but refers to the time before the revelation of the Qur'an to Muhammad.

18 "The rightly guided Caliphs", meaning the first four Caliphs of Islam.

19 "The people who loose and bind."
} 
Husayn or a religious leader of the Turks, but disqualifies the former because of his lack of formal education, and the latter because of their opposition to the very idea of an existing Caliphate (Ibid: 74). The one person he does see as qualified is Imam Yahya of Yemen. But due to him being a Shiite, and the fact that many Sunni centers of faith must bear allegiance to him, it seems impossible that such a candidate would be accepted by the Muslim community (Ibid). Rida also discusses the difficulty in finding a suitable location for the Caliphate to be seated. His choice is somewhere between Turkey and Arab lands, a so called 'intermediary zone' by Inayat (Ibid 75). This would be accomplished with cooperation from both sides, so the strength of each respective culture and society may balance out the weakness in the other.

5.3: Reaction by Egypt's intellectuals

There were several controversial publications in this period that undermined the traditional interpretation of Islam. In 1926, Egyptian Professor Taha Hussayn published an essay on pre-Islamic poetry arguing that ancient poetry was manufactured for intertribal reasons and hints that the Qur'an may not have been divinely inspired (Hourani 1982: 327).

Compared to Rashid Rida, there could not have been a more contradictory position regarding the Caliphate than that taken by Ali 'Abd al-Raziq in his 1925 treatise "Islam and the Foundations of Political Power". Published a year after Rida's work, 
Raziq unequivocally denounces the Islamic legal tradition justifying the Caliphate. Each chapter is systematically presented and studied to determine whether the Qur'an and the Hadith advocate for an Islamic superstructure. While his most vehement statements are reserved for the conclusion, each chapter contains nothing short of revolutionary statements defying the entire history of Quranic exegesis towards Islam's most powerful institution.

The book is divided into three 'books', each containing three chapters. The first third investigates Quranic injunctions largely interpreted as calling for the Caliphate's presence. Two verses he closely analyzes ${ }^{20}$ call for Muslims to obey those 'set in authority over you'. In a terse analysis Raziq concludes that "We do not know of any scholar who claims to find support in these verses for either of the two proposals in question" but rather the importance of an Imam in a community ('Abd al-Raziq 2012: 37). In this issue he directly addresses Rida's quest to find evidence for the Caliphate in the Quran and the Hadith. Rida relies on a hadith that spoke of "a binding obligation for the whole community of Muslims and their Imam”. Raziq takes this hadith in conjunction with others and interprets them as requirements necessary to be an Imam, not the necessity of a global leader. Additionally, Raziq makes his first of two allusions to Jesus Christ's well known statement to 'render unto Caesar what is Caesar's'. ${ }^{21}$ "The above allusions to the concepts of 'caliphate', 'imamate' and 'allegiance' in the Prophet's hadiths do not mean anything beyond what Christ meant when he referred to the legal requirements pertaining to the government of Caesar" (Ibid: 41).

\footnotetext{
${ }^{20}$ Qur'an 4:59 and 4:83

${ }^{21}$ Matthew 22:21
} 
Due to the many references regarding allegiances, power and government in the hadiths, Raziq understands how legists concluded the requirement for a Caliphate (Ibid). However, Raziq criticizes these interpretations as excessive, rigid, and counter to other rulings regarding other important social issues. "[D]ivorce, borrowing, commerce, mortgaging and so on, [are] mentioned frequently in God's book and plainly regulated in his law. This does not mean that these issues are religious duties, or that they have a special significance for God" (Ibid).

Such a clear conclusion for Raziq led him to wonder how other jurists and theologians missed this point as "The issue of the caliphate is not only passed over in the Qur'an, it is equally ignored in the Sunna" (Ibid: 38). Raziq reasons that a neglect of political science and any "inquiry into systems of government or the foundations of political life" are at fault (Ibid: 44). Muslim scholars were certainly not ignorant of this subject as works from Plato and Aristotle were translated by Muslims in the medieval ages. The fault lies on the imamate itself, which, quoting Rida, "which functions through those who pledge...having consulted among themselves, to be the leader of the community and the imam of the umma" (Ibid: 46). Raziq counters this notion by stating history shows "the caliphate was founded not on voluntary allegiance but rather by sheer coercion, and that in most instances this took the form of a physical, military coercion" (Ibid: 46-47). ${ }^{22}$

\footnotetext{
${ }^{22}$ Space does not permit a complete reading of some of Raziq's thoughts and his seeming disgust with the results of the caliphate institution. I state this with strong certainty as Raziq writes "If it were not for the risk of pushing our discourse beyond acceptable limits we would have presented evidence of repression and coercion with regard to every caliph...Crowns are preserved only at the expense of human lives. The power of rulers is upheld by destroying the power of humankind... Their light springs from the glimmer of swords and flames, ignited in wars" (Ibid: 47).
} 
Thus, a crucial component of Islamic law, ijma', was never properly applied. Raziq argues that the caliphate was not established by consensus of the community, but by the power of the sword. ${ }^{23}$ Therefore, "they behave like wild beasts towards men who defy them or attack their position. It also follows that they should oppose intellectual inquiry, even of the most scientific kind, if they suspect that it constitutes a threat, however uncertain" (Ibid: 50). Because political science "poses an especially strong threat to those in power" rulers opposed it as a pursuit of study and the caliphate as a critical topic of examination.

The remainder of the book is an in depth study of the purpose of Muhammad's message and whether he came to establish a religion, state, or both. Influential Muslim historians like Ibn Khaldun and Rifa'a al-Tahtawi provide lengthy explanations for the system of power in place, but Raziq counters this historical tradition by arguing there is little to no evidence of Muhammad calling for its establishment. "Why did the prophet not speak to his subjects about government and about the rules of popular consultation" (Ibid: 74). Not only are past prophets or messengers not kings ${ }^{24}$ the Qur'an is clear that the Prophet had no interest in political power (Ibid: 87 ). ${ }^{25}$

Raziq extends this argument to the first Caliph Abu Bakr who received religious devotion by many Muslims due to his relationship with the Prophet. Any insurrection

\footnotetext{
${ }^{23}$ He lists several examples like Yazid attacking Medina in the time of Muhammad, Ibn-Marwan and the Umayyad dynasty as well as Ibn Abbas

${ }^{24}$ Though he states this is the fact "In general", he again cites Jesus' statement of rendering unto Caesar what is Caesar's. It is ironic he directly cites Jesus' words, who also stated "My kingdom is not of this world". I do not assume that Raziq's mention of "In general" alongside Jesus' words are a tacit acknowledgment of Jesus' proclamation.

${ }^{25}$ Raziq cites over a dozen verses to include 4:80, 6:66-67, 42:48, 50:45, 88:21-24
} 
against Abu Bakr was seen as an attack on the faith itself. Therefore, some of those "who rose against Abu Bakr were not all apostates in the sense of repudiators of belief in God and his Prophet" (Ibid: 112). Some of those killed were not apostates, but disputed based on their tribal affiliation. Thus, "it was in the interest of the rulers to propagate this fiction [of the caliphate] among the people. They did so with a view to protecting their throne and suppressing their opponents in the name of religion" which served to "kill the vital impulses of intellectual inquiry among Muslims" (Ibid: 116-117).

Part of the danger, and one of the major reasons Raziq was attacked vociferously was his standing in the community. He graduated as an 'alim from al-Azhar in 1915 and later became a judge in the Islamic courts in Alexandria. Raziq was not a journalist or orientalist, but an Islamic scholar trusted to safeguard Islam's storied past and extensive jurisprudence. Rashid Rida stated "it was the latest attempt of the enemies of Islam to weaken and divide it form within" (Hourani 1982: 189). "The book led to the first trial of an intellectual for his ideas in modern times" and was heatedly discussed in Egyptian newspapers. ${ }^{26}$ The leading council of al-Azhar unanimously dismissed him from the 'ulama and erased his name from all of Azhar's records (Adams 1968: 261). Several scholars in Egypt refuted Raziq's thesis to include Muhammad al-Khidr and Muhammad Bakhit who criticized Raziq for quoting non-Muslim scholars (Broucek 2012: 210).

Raziq's work disrupted efforts by officials invested in resuscitating the caliphate in Cairo. The Congress held a year later would suffer from its own shortcomings, but Raziq's analysis discredited the concept of a caliphate entirely. Why revive something

\footnotetext{
${ }^{26}$ Translators note, (pg.6)
} 
that is lost, and was not necessary if not damaging to the Muslim community in the first place? Many Egyptians, enthused by the success of the Wafd party's success, were eager to achieve complete freedom of affairs and become an independent nation. Raziq closes his essay with a thought, "There is not a single principle of the faith that forbids Muslims to co-operate with other nations...[or] prevents them from dismantling this obsolete system, a system which has demeaned and subjugated them...[and] Nothing stops them from building their state and their system of government on the basis of past constructions of human reason” ('Abd al-Raziq 2012: 118).

\section{4: 1926 Cairo caliphate congress}

Publicly, King Fu'ad and Zaghlul, leader of the Wafd, pledged noninvolvement in the issue. Behind the scenes, Fu'ad used his power to fill positions in the Army and Azhar to bolster his influence throughout the country (Goldschmidt 2004: 75). Shortly after the actions of the assembly in Turkey, one of the king's appointees in the Ministry of religious endowments went to several cities throughout Egypt which suspiciously spawned caliphate committees after his arrival (Kedourie 1970: 185). Additionally, it was revealed after the congress that the same ministry dispensed monies quickly and disregarded formal procedure from 1924-1925. It subsequently "appeared that the money was spent on the caliphate congress" (Ibid: 184, Kramer 1986: 89). It appears that the palace funded the propagation of a periodical from October 1924 until the congress was held (Kramer 1986: 88). There is wide consensus that while the initiative began with al- 
Azhar, it was covertly co-opted by the palace. (Gershoni and Jankowski 1987: 59, Kedourie 1970: 189, Kramer: 1986: 89).

Opposition to the congress first rose from religious circles. The 'Supreme Caliphate Committee' formed in March 1924 by Abu al-'Azim recognized the deposed Caliph 'Abd al-Majid. Their efforts to form a congress ran in parallel with those of alAzhar and "had some effect in making Muslim opinion outside Egypt skeptical about the aims of official efforts toward a Congress" (Gershoni 1986: 59). 'Azim led an unofficial delegation of Egyptians to a rival caliphate conference held in Mecca by Ibn Sa'ud, a mere month after the Cairo congress concluded (Kedourie 1970: 193). What significantly aided this committee's efforts was the backing of a wealthy Alexandrian prince, Umar Tusun, who was spurned by the palace initially and decided to support a popular Sufi sheikh (Kramer 1986: 89).

Another influential conservative leader, famous for his role in prosecuting Raziq, opposed the congress because Egypt was not governed by sharia' and instead supported the Afghans (Ibid: 90). Further frustrating efforts at unity was an initiative by 40 'ulama of al-Azhar declaring Egypt unfit as the seat of the Caliphate (Kedourie 1979: 193). The timing of this action, five months before the congress, came at an inopportune time for an institution already suffering from poor organization.

The largest groups opposed to the congress were secular nationalist parties. The Liberal Constitutionalist party, of which Raziq was a member, took a particularly firm stance. They argued that since article 47 of the constitution forbade the King from obtaining other authority without parliamentary approval, even if Fu'ad desired the 
religious appointment it would have to be approved by a secular elected body (Kedourie 1970: 190). Zaghlul and elements of the Wafd party even went so far as to financially support the rival caliphate congress of Umar Tusun (Kramer 1986: 90). These efforts were supplemented by sympathetic journalists allied with the major representative bodies (Ibid: 189).

Most unfortunate for the organizers of the congress was the negative response from Muslims abroad. It was especially damaging since Muslims around the world were the target audience. One of the goals was to achieve widespread consensus on the nature of the caliphate as to who was qualified to lead. Through the passage of time this objective became increasingly untenable. A few weeks after Azhar's announcement to convene a Congress the chief judge of Transjordan "denounced the congress as an innovation which was contrary to religion" (Toynbee 1927: 84). Major Muslim centers like Turkey and Afghanistan failed to send any representation (Gershoni and Jankowski 1987: 65). Indonesia and Java who had increasing ties to the Muslim community in Cairo only sent two representatives. India, which underwent a massive social movement because of the threat to the caliphate only sent one representative, and they did not represent the largest organization or 'ulama in their home country (Ibid).

Despite these setbacks, the congress convened in May, 1926. In March, 1924 the aspired goal was the election of a new caliph. However, after two years of religious factionalism and competing rivalries, expectations significantly lowered. The six point program that was discussed merely aimed at articulating the nature of the caliphate and what work lay ahead; even in that it failed. The final memorandum failed to advance the 
cause of the caliphate and merely acknowledged longstanding public sentiment. "The Congress has decided: That the Islamic Caliphate in conformity with the prescriptions of the Shari'ah is capable of realization...That it is desirable to avoid, in this regard, anything which might create division among Muslims” (Toynbee 1927: 89). The remainder of the resolution called for equal representation of Muslims in conferences that were to follow.

For the amount of exposure al-Azhar and the 'ulama in Egypt dedicated to the caliphate issue, the congress was an unremarkable event. The event lasted barely a week, and failed to reach consensus on any meaningful issues. The palace and Azhar's 'ulama risked their reputation as well as their treasure to serve as the center of a new Pan-Islamic assembly. The next Muslim congress would never return to Egypt despite a resolution calling for an assembly after a one year hiatus. It would instead be held in Palestine, where regional energies were directed toward opposing the development of a Jewish homeland. The charter adopted by the Palestine congress in 1931 reflects the change in priorities. The articles stressed the aims of defending "Muslim interests and preserve the holy places and lands from any intervention, combat[ing] Christian missionary efforts and campaigns among the Muslims...to examine other Islamic matters of importance to the Muslims" (Kramer 1986: 192). While the caliphate was still a topic of discussion at the time, it was not important enough to be mentioned anywhere in the charter's seventeen articles.

Domestic politics in Egypt proved to be just as divided and fruitless as efforts to organize the caliphate congress in Cairo. Moreover, autocratic decisions by King Fu'ad 
undermined the popular vote of the people over several years. The Wafd party won a majority vote from 1925-1927 but saw its victories erased either by the King dismissing parliament or the British high commissioner refusing to let Zaghlul take power (Botman 1998: 290-293). Exacerbating the situation was an economic depression from 1929-1933 that wiped out previous booms in cotton production (Sayyid-Marsot 1977: 121). Three years after Zaghlul's passing, one of the most dynamic and revered political leaders by the Egyptian masses, the 1923 constitution was suspended and for five years Egypt lived under a "virtual Palace dictatorship" (Goldschmidt 2004: 77).

\section{5: Formation of the Muslim Brotherhood}

In this context, it is not difficult to see why certain civil society groups would flourish in Egypt. Many social and religious organizations formed in Egypt in the 1920’s; the Islamic Guidance Society (1928), the Society of the Islamic Banner (1927), and the Society of the Eastern Bond (1922-1931). Among them, none crafted a legacy like the Muslim Brotherhood. The Brotherhood resonated with the Egyptian people like no other organization, and expanded throughout the Islamic world. Arguably, there is no other Muslim association that has been more consequential in world affairs.

Hassan al-Banna, the organization's founder, was deeply influenced by events following World War I. While attending a teacher's training school in Cairo from 19231927, he noted in his memoirs that a "wave of atheism and lewdness engulfed Egypt. It 
started devastation of religion and morality on the pretext of individual and intellectual freedom...The circumstances had made it more dangerous" (Al-Banna 1981: 109).

These circumstances, as his next sentence reads, are not entirely beholden to local events in Egypt. "Mustafa Kamal brought about a revolution in Turkey by abolishing the caliphate. He separated the state from religion." Al-Banna interprets the government takeover of the university system in Turkey not as modernizing education, but as destroying religion. "The essence of the new concept was that a university could not become a secular university until it waged a crusade against religion and its social traditions. Hence the university adopted the western materialistic thought and culture and its teachers and students relieved themselves of all the moral restraints" (Ibid: 109-110). Essentially, Islam and its moral foundation was under attack by the removal of the caliphate and a secular takeover of the educational system.

Egypt was also ensnared by this newfound innovation. "There was a serious reaction among those who were interested in westernism and atheism as for example Azhar and other Islamic centres and institutions...I felt that my cherished Egyptian nation was rolling a state of suspended animation between the two ideologies... On the one hand there was their revered faith Islam... and on the other hand there was a fierce attack of the western thought and culture to destroy the old values of life" (Ibid: 110-111).

Though Al-Banna was only seventeen when the caliphate was abolished, and in his early twenties while in Cairo, it was a formative period of his life. He found solace in likeminded students but "The camp of atheism and westernism was getting stronger and stronger; whereas the Islamic camp was growing weak day by day." After internalizing 
the tragedy befalling his faith, al-Banna reasoned, "Why should I not throw this responsibility on the Muslim leaders? I should tell them to rise unitedly and thwart the evil designs of the atheists. If these gentlemen agree to my view, it is well and good, otherwise I shall have to find some other ways and means" (Ibid: 111-112).

Despite its popularity, the Muslim Brotherhood was not the first organization alBanna helped established. In 1927 while still in Cairo, al-Banna responded passionately to an older Sheikh who heard Banna's complaints about society and advised him "to continue my mission in the best possible way and leave the results to Allah" (Ibid: 113). Incensed at this complacent attitude, al-Banna retorted "Sir, Islam is being attacked vehemently by the enemies, but the followers of Islam and their leaders are wasting their time in eating sweets" (Ibid: 115). That evening, the Sheikh along with al-Banna and several others started the Young Men's Muslim Association. They started a weekly newspaper "to counter the western and atheistic trend. We can also produce the Islamic literature to cure the diseases spread by the enemies of Islam."

A year later al-Banna was assigned to Ismailiya, a city located just west of the Suez Canal. He lamented the pervasive foreign influence where Muslims are treated "just like slaves. But the foreigners are accorded full respects and given the status of officers and rulers" (Ibid: 140). Al-Banna when reflecting on Ismailiya is particularly fixated on Britain's cultural imperialism in all domains of Egypt's society. The foreign employees live in comfortable bungalows while the Arabs are in huts, signboards are in European languages, even the name of the mosque is written in French. "The environment of Ismailiya created very deep impression on my mind and these 
impressions helped me a great deal in the determination of my mission and my career as a preacher" (Ibid: 140-141). One evening, six other Egyptians who worked under the British formed with al-Banna the first branch of the Muslim Brotherhood.

Al-Banna believed it was important to reform Egyptian society by revitalizing Islamic faith. However, his long term goal was much more ambitious. Al-Banna writes in one of his tracts 'Our mission in a new stage', "We want to establish [an] Islamic state in Egypt, which will adopt the principles of Islam, unite the Arabs and work for their welfare, relieve all Muslims of the world from the tyranny and oppression and propagate Islam and enforce the laws of Allah". ${ }^{27}$ This was needed as he writes, "there is no authority in Islam except the authority of the state which protects the teachings of Islam and guides the nations to the fruits of both religion and the world" (Mitchell 1968: 244).

Al-Banna's organization would expand throughout Egyptian society from four branches in 1929, to 300 in 1938 (Mitchell 1969: 328). The Muslim Brotherhood would expand to over several thousand by 1949 and remain an important segment of Egyptian society until present day. Al-Banna set the intellectual blueprint for ideologues like Sayyid Qutb and Ayman al-Zawahiri. These ideologues defined the religious programs not just of Muslim associations in Egypt, but of movements throughout the world who mobilized to defend their faith and spread their interpretation of Islam.

The fall of the caliphate did not animate a significant portion of Egyptian society as many segments were relishing their newfound, quasi-sense of independence. The new constitution and elections were a direct result of the cessation of hostilities in World War

\footnotetext{
${ }^{27}$ Translator's introduction of al-Banna's memoirs, pg.32.
} 
I and political acuteness by several Egyptian leaders. The reaction by traditional segments, embodied in al-Azhar, was partially a result of a loss of cultural and political relevance in society. An attempt to resurrect their fortunes failed in the form of a congress held in Cairo, and only further revealed divisions of religious interpretation in society. This did not prevent the development of a nascent civil society founded on an anticolonial sentiment with Islam as a basis of social organization. Political gridlock, economic malaise, and a shared sentiment among Egyptians as second place citizens in their own country fueled the rise of the Muslim Brotherhood and one of the most consequential Muslim organizations in recent history. 


\section{CHAPTER 6}

\section{CONCLUSION}

Each of the countries reviewed reacted differently to the removal of the caliphate. For British India, the threat to the caliphate was enough to generate a massive nationwide response that crossed ethnic and religious boundaries and persisted for several years. The strongest response in Egypt originated from the religious leadership in al-Azhar. From Turkey's perspective, the caliphate was an anachronistic institution in the modern world and held the new republic back from 'true' civilization. The response by each country to this momentous event was heavily influenced by their exposure and experience with colonial powers, as well as local constructions of nationalism and secularism.

In Turkey, the history of colonial rule was non-existent. Perhaps because of this, colonial subjugation counterintuitively empowered Atatürk to mobilize both secular and religious minded masses to his cause. The first oppositional congress formed in 1919 elected Mustapha Kemal as their president and published a ten point declaration stating "the national forces must be put in charge to preserve the national independence and to protect the sultanate and caliphate..." (Zürcher 2000: 150).

Crucial in his rise to power, Atatürk successfully took advantage of this crisis by claiming to defend Islam from foreign invaders and respect the establishment of the caliphate. He was embraced not only by his fellow countrymen, but by a multitude of Muslims in India who organized a movement based on the prospect of the caliphate 
maintaining its existence and symbolic power. However, as proven in this study, he saw the mantle of the caliphate only as a hindrance to the development of Turkey as a nation. A truly civilized nation, in Atatürk's view, could only be measured vis-a-vis its contemporaries in modern day Europe, not by Islamic precedent.

Throughout Atatürk's rise and quest for a sovereign state, he inculcated and indeed legislated his secularist tendencies into the fabric of the new nation. Atatürk used legislation to remove the influence of religion and weight of religious authority in society. By salting the fertile soil of Turkey's revolution, he eliminated the prospect of civil society bearing any fruit of opposition or an indigenous counter-revolution.

Such actions enabled the presidency to displace critics who otherwise might have been able to mobilize strong opposition. An excellent case in point is Mustafa Sabri, one of the last Grand Mufti's of the Ottoman Empire. Sabri was one of the most feared opponents of the CUP due to his prodigious knowledge and oratory skills (Özoğlu 2011: 43). Forced to leave Turkey in November 1922 because of his opposition to Atatürk's new government in Turkey, Sabri moved to Egypt (Karabela 2003: 46). However, his criticism of Atatürk made him unwelcome and he relocated to Lebanon (Ibid: 47). While the possibility existed to return to his home country and use his reputation to join or start a new party, Atatürk made the decision for him. Less than three months after abolishing the caliphate, Sabri was the ninth person listed out of the 150 considered personae non grata in Turkey (Özoğlu 2011: 43).

For good measure, Atatürk banned Sabri's son as well, who helped edit some of his father's works. By the end of 1924, Sabri finished penning his work "The Rejection 
of Those Who Criticize the Benefits of Religion". This criticism focused on the actions of abolishing the caliphate, the ministry of religious affairs, and the Turkish revolution in general (Karabela 2003: 57). Sabri's work might have gained a greater audience and more exposure in Turkey, or certainly in Egypt, but Atatürk's list of 150 personae non grata banned him from the first and Atatürk's support in the Islamic world pushed him from the second. Atatürk's influence was so great that he was able to put diplomatic pressure on Greece and ask Sabri to leave the country where he was publishing a newspaper critical of the new government in Ankara.

In India, British colonialism had a long history before the caliphate was threatened by Istanbul's occupation. It began with extensive commercial exploitation and was later solidified by a government takeover of a British company's assets. The end of World War I spawned the creation of the Khilafat Committee, whose leaders were widely embraced because of their historical defiance of British authorities. Despite diverse platforms, four organizations representing a panoply of interests rallied to form the Khilafat movement.

What tested the integrity of the movement was not the overt policies of British overseers, but the cogency of the newfound political partnership of Hindus and Muslims. Violent clashes and failed accords manifested the mounting dissension of this nascent Pan-Indian organization. By the time the caliphate was officially abolished in 1924 , the Khilafat movement was waning and local interests took precedence. Replacing the PanIndian movement were several regional political groups aligned around ethnic and religious identities. 
Most importantly, leaders of dominant political organizations in India lamented a seemingly unbridgeable divide and pondered quite seriously the idea of two separate nations. The development of territorial nationalism in this period preceded the creation of two nations that embodied the physical geography of these nationalist movements. In this case, secularism was not a contributing factor to the mobilization of Muslims in India but the belief that two different religious societies were incompatible.

The mobilization of Muslims in Egypt emerged along two different fronts. The first was the caliphate congress, an initiative of al-Azhar and King Fu'ad. They intended the gathering of the world's Muslims to serve as a clarion call to elect a new Caliph. However, dissension within Egypt about Islam's role in society and a burgeoning independence movement disrupted the plans of Egypt's traditionalists.

The interregnum between the abolishment of the caliphate and the congress in Cairo exposed the discord within Egypt and Muslims throughout the world about the future of Islam. This intellectual struggle contributed to the dissipation of the congress' original goals and its eventual futility. One of the main elements of discussion was the impact of colonialism.

Individuals who were immediately disqualified to serve as caliph were disqualified not primarily due to religious qualifications, but to the extent their lands had been tainted by colonial interference. Fu'ad's main competitor in Egypt used this as a basis to delegitimize the 1926 congress. A history absent of western control is one reason why Afghanistan was favored by some as the logical place (Kramer 1986: 90). Afghanistan's stature as a pure land unscathed by colonialist intrusions motivated the 
mass migration of Muslims from British India in 1920 during the Khilafat movement in India.

The second front of mobilization arose from the lay Muslim concerned with the state of Islam. The apprehension in Egypt, especially by Hasan al-Banna and other groups, was the colonization not just of land but of the minds of the people. A tract by the Islamic Guidance Society stated that "the Muslim pupil [in Egypt] does not know the history of the Prophet as well as he knows the history of Napoleon" (Gershoni and Jankowski 1995: 88). Raised as a Muslim but a teacher by trade, the crisis for al-Banna was twofold; the British occupation that subordinated Muslims in their own country and a lack of education and zeal by Muslims to reform and revitalize society. Al-Banna believed along with others joining him that a nation could not be built on secular notions as they corrupted lives, society, and held Egypt back from its true potential.

While the removal of the caliphate had a profound impact on the major Muslim centers of Egypt, Turkey, and British India, it can be argued that the end of World War I and subsequent occupation of Istanbul had an even greater effect. Within Turkey, this triggered a struggle over the future of the country with both sides claiming to defend Islam. The Khilafat movement in India, while motivated to protect the caliphate, was incited by the occupation of Istanbul. By the time the caliphate was actually abolished, the Khilafat movement had lost all momentum and relevancy in British Indian society. The peace conference of 1919 sparked off a year of revolt in Egypt amid promises of self-determination by American president Woodrow Wilson. The period of 1919-1923 
was a struggle to rid the yoke of British imperialism off the Egyptian people and achieved a modicum of success in the 1923 constitution.

In these three cases, the end of World War I incited nationalist ambitions. Besides Ataturk playing the part of a Muslim liberator, the major representative bodies in Turkey, British India, and Egypt, formed their movement under a modernist political platform. Even within India, the Khilafat movement did not call for the imposition of Islamic law, but the protection of a symbolic institution abroad and greater political liberty domestically. Likewise in Egypt, Sa'ad Zaghlul used his technocratic skills to push for a nationalist agenda. He marginalized religious concerns either out of expediency or personal conviction. Based on his own experience as an assistant to one of the chief British administrators, Zaghlul likely saw religion as a less important factor in the modern construct of a nation-state.

The consequences for critical juncture theory, especially the concept of path dependency, is quite apparent in the study of Turkey, British India and Egypt. Path dependency is defined as a point where "once a particular option is selected, it becomes progressively more difficult to return to the initial point when multiple alternatives were still available" (Capoccia and Kelemen 2007: 347). There were many possibilities in Turkey after the occupation of Istanbul and resulting domestic struggles. Atatürk could have been defeated by a more moderate Muslim who was less averse to Islam's role in society. The caliphate might have been maintained and magnified Turkey's role in international affairs. 
Significantly, these consequences would have reverberated throughout the Muslim world and severely disrupted political projects in other nations. The caliphate congress would have likely never occurred and the Khilafat movement might have been rejuvenated by the preservation of the caliphate in Istanbul. There could have been unified responses to colonial powers led by the caliph in Turkey. Conversely, colonial powers might have seen wisdom in negotiating for a phased withdrawal from these countries after reaching an agreement with the caliph and his representative regents in the Islamic world. Could the crisis of authority as Frances Robinson and Richard Bulliet phrase it been averted by the maintenance of the caliphate in Turkey? Fringe, radical elements of Sunni Islam would have little resonance in society if the caliphate was still viewed as an authoritative arbiter.

While this might seem to be a mere exercise in counterfactuals, it underscores the importance of events from 1919-1924 in the history of Islam. Many alternative timelines were possible, but the occupation of Istanbul and removal of the caliphate as an institution of Islam fundamentally transformed the political and religious culture of Muslims throughout the world. Turkey became a secular country where Islam was repressed for decades. After a failed attempt at Pan-Indian unity the ground for partition was set by the end of the 1920's. Egypt struggled against colonial interference and Muslims mobilized to revitalize a faith they felt was abandoned at the footsteps of westernized notions of progress.

This study reveals how the mobilization of Muslims and their religious programs, or lack thereof, greatly affects those outside their borders. The project of Muslims in one 
corner of the globe can be tremendously intertwined with the success of another movement. Whether Muslims in the process of organizing a movement take into account how their decisions affect other Muslim movements deserves further inquiry.

How this is done acts as a bellwether to the notion of a transnational 'umma, and the potential of international developments to transcend previously unbridgeable divides. For example, the threat to the caliphate compelled interaction between radically different denominations. The Azhar committee sent invitations to Wahhabis, Shi'a, and Isma'ilis (Kramer 1986: 91). Similarly Abd al-A'zim, Azhar's domestic competition for the caliphate personally visited Qum and other Iranian religious leaders (Ibid). The Khilafat struggle united Shia's because they "shared Sunni anxiety over the decline of Muslim power and the uncertain condition of the holy places" (Minault 1982: 73). For Shia' leaders in India, "political arguments triumphed over theological ones" because of the movement's mass popularity (Ibid: 97). Moreover, it was not developments in India or other events in the Muslim world but the expressed concern by two Shia' that provided Atatürk the pretext to abolish the caliphate.

Another example is seen in the 1931 Jerusalem conference organized by the Grand Mufti of Jerusalem Amin al-Husayni. Al-Husayni developed the conference after years of cooperating with the "Ali brothers in British India. The event was to serve alHusayni's purpose of bringing attention to the Muslim cause in mandate Palestine, and Shaukat Ali's desire for a Pan-Islamic organization (Kupferschmidt 1987: 192-194). The event encouraged cross-denominational dialogue by having an Iraqi Shia' lead Friday 
prayers and al-Husayni himself stating "there was every prospect of an early reunion between the Sunnis and the Shia's" (Ibid: 198). ${ }^{28}$

By contrast, the case of Egypt and the Saudi state demonstrate how burgeoning independence movements were unable to establish friendly bilateral relations. Despite their proximity and shared culture, both countries jealously guarded self-rule. King Fu'ad's political ambitions in the Hijaz, and competing caliphate congress ensured that the "largest independent Arab states of the interwar period existed in technical isolation from each other" (Gershoni and Jankowski 1987: 244).

At a time of unparalleled change in the Muslim world, cooperation was a struggle when not facing a common enemy. An analysis (Khan 2006) of the Egyptian and Indian nationalist movements argues that cooperation between these two countries was not based on any Pan-Islamic identity but a supra-national identity of oppressed peoples. She argues that leaders of these movements wanted empires to cease not just as western colonies, but as political organizations. It is possible that efforts to combat Western imperialism simultaneously inculcated a reluctance to embrace a similar structure of government even if there was historical precedent in the community. Further research should be conducted to determine whether anti-imperialist movements succeeded in attenuating the desire for Muslims to rally behind a revived Muslim empire.

\footnotetext{
${ }^{28}$ This was preceded in 1923 with delegations being sent to Iraq and Iran at the behest of al-Husayni to plead the case of the Supreme Muslim Council in Jerusalem (Ibid).
} 


\section{Bibliography}

'Abd al-Rāziq, 'Alī. Islam and the foundations of political power. Translated by Abdou Filali-Ansary, and Maryam Loutfi, Edinburgh: Edinburgh University Press, 2012

Adams, Charles C. Islam and Modernism in Egypt: A Study of the Modern Reform Movement Inaugurated by Muhammad 'Abduh. New York: Russell \& Russell, 1968.

Allawi, Ali A. The Crisis of Islamic Civilization. New Haven, Conn: Yale University Press, 2009.

Ariate, Joel F. "Contending with the Crisis of Islam and the Myth of Confrontation", Kassarinlan: Philippine Journal of Third World Studies, 2003, Vol.18 No.1-2.

Ardic, Nurullah. Islam and the Politics of Secularism: The Abolition of the Caliphate (1908-1924). Thesis (doctoral)—University of California (Los Angeles), 2009.

Arnold, Thomas W. The Caliphate. Oxford: The Clarendon press, 1924.

Atatürk, Kemal. A Speech Delivered by Ghazi Mustapha Kemal, President of the Turkish Republic, October 1927. Leipzig: K.F. Koehler, 1929.

Bannā, Hasan. Memoirs of Hasan Al Banna Shaheed. Karachi: International Islamic Publishers, 1981

Botman, Selma. "The Liberal Age, 1923-1952" in Petry, Carl F., and M. W. Daly. The Cambridge History of Egypt. Cambridge: Cambridge University Press, 1998.

Broucek, James. The Controversy of Shaykh 'ali 'abd Al-Raziq. Thesis (doctoral) - The Florida State University, 2012.

Bruinessen, Martin van. Agha, Shaikh, and State: The Social and Political Structures of Kurdistan. London: Zed Books, 1992.

Bulliet, Richard W. The Case for Islamo-Christian Civilization. New York : Columbia University Press, 2004.

Bulliet, Richard W. “The Crisis Within Islam”, Wilson Quarterly, Winter 2002.

Capoccia, Giovanni and R. Daniel Kelemen, "The Study of Critical Junctures: Theory, Narrative, and Counterfactuals in Historical Institutionalism”, World Politics, no.59, April 2007, pp.341-369. 
Cleveland, William L. A History of the Modern Middle East. Boulder: Westview Press, 2004.

Davison, Roderic. Essays in Ottoman and Turkish History, 1774-1923: The Impact of the West. University of Texas Press, Austin, 2001.

Gandhi, and Shriman Narayan. The Collected Works of Mahatma Gandhi. Volume 23 (March 1922-May 1924). Navajivan Press, Ahmedabad, 1967.

Gandhi, Mahatma. Gandhi, an Autobiography: The Story of My Experiments with Truth, translated from the Gujarati by Mahadev Desai, London: Phoenix Press, 1949

Gershoni, I., and James P. Jankowski. Egypt, Islam, and the Arabs: The Search for Egyptian Nationhood, 1900-1930. New York: Oxford University Press, 1986

Gershoni, I., and James P. Jankowski. Redefining the Egyptian Nation, 1930-1945. Cambridge: Cambridge University Press, 1995.

Goldschmidt, Arthur. Modern Egypt: The Formation of a Nation-State. Boulder, Colo: Westview Press, 2004

Gülalp, Haldun, "Enlightenment by Fiat: Secularization and Democracy in Turkey", Middle Eastern Studies, 2005, Vol.41(3), p.351-372

Haddad, Mahmoud. "Arab Religious Nationalism in the Colonial Era: Rereading Rashid Rida's Ideas on the Caliphate." Journal of the American Oriental Society. Vol. 117 (1997): 253-277.

Hasan, Mushirul and Margrit Pernau. Regionalizing Pan-Islamism : documents on the Khilafat Movement, New Delhi : Manohar : Distributed in South Asia by Foundation Books, 2005

Hassan, Mona F. Loss of Caliphate: The Trauma and Aftermath of 1258 and 1924. Thesis (doctoral) —Princeton University, 2009.

Hitti, Philip K. The Arabs: a Short History. New York: St. Martin's Press, 1968

Hogan, John. "Remoulding the Critical Junctures Approach", Canadian Journal of Political Science, vol. 39, no.3, pg. 657-679

Hourani, Albert. Arabic Thought in the Liberal Age, 1798-1939. London: issued under the auspices of the Royal Institute of International Affairs [by] Oxford U.P., 1970

'Ināyat, Hamīd. Modern Islamic Political Thought. Austin: University of Texas Press, 1982. 
Iqbal, Muhammad. Shikwah, Jawab-I-Shikwah (Representation and Reply). Translated by Raja Sultan Zahur Akhtar, Iqbal Academy Pakistan, Lahore, 1998.

Iqbal, Muhammad. The Reconstruction of Religious Thought in Islam. Muhammad Ashraf, Kashmiri Bazaar, Lahore, Pakistan, 1962.

Jackson, Patrick Thaddeus. The Conduct of Inquiry in International Relations. Routledge 2011

Karabela, Mehmet Kadri. One of the last Ottoman Seyhulislams, Mustafa Sabri Efendi (1869-1954): His Life, Works and Intellectual Contributions. Thesis (masters)McGill University, Montreal Canada, 2003.

Karandikar, Maheshwar. Islam in India's Transition to Modernity. Westport, Conn: Greenwood Pub. Corp, 1969.

Keay, John. India: A History. New York: Atlantic Monthly Press, 2000.

Kedourie, Elie. The Chatham House Version, and Other Middle-Eastern Studies. New York: Praeger, 1970

Kerr, Malcolm H. Islamic Reform; The Political and Legal Theories of Muhammad 'Abduh and Rashīd Riḍā. Berkeley: University of California Press, 1966

Kersten, C., and Madawai al-Rasheed. Demystifying the Caliphate: Historical Memory and Contemporary Contexts. London: Hurst \& Company, 2013.

Khan, Noor-Aiman Iftikhar. The enemy of my enemy: Indian influences on Egyptian nationalism, 1907-1930. Thesis (doctoral) —University of Chicago, 2006.

Kinross, Patrick Balfour. Atatürk: A Biography of Mustafa Kemal, Father of Modern Turkey. New York: Quill/Morrow, 1992

Kramer, Martin S. Islam Assembled. New York: Columbia University Press, 1986.

Kupferschmidt, Uri M. The Supreme Muslim Council: Islam Under the British Mandate for Palestine. Leiden: E.J. Brill, 1987.

Lewis, Bernard. What Went Wrong? Western Impact and Middle Eastern Response. Oxford: Oxford University Press, 2002.

Lewis, Bernard. The Crisis of Islam: Holy War and Unholy Terror. New York: Modern Library, 2003. 
Lewis, Bernard. The Emergence of Modern Turkey. London: issued under the auspices of the Royal Institute of International Affairs [by] Oxford U.P., 1968.

Lewis, Bernard, "The Ottoman Empire and its Aftermath", Journal of Contemporary History, 1980, Vol.15(1), pp.27-36

Malik, Iftikhar H, "Identity Formation and Muslim Party Politics in the Punjab, 18971936: A Retrospective Analysis", Modern Asian Studies, 1995, Vol.29, (2), pp.293-323.

Mango, Andrew. Atatürk: The biography of the founder of modern Turkey. Woodstock, N.Y.: Overlook Press, 2000.

Minault, Gail. The Khilafat Movement: Religious Symbolism and Political Mobilization in India. New York: Columbia University Press, 1982.

Mitchell, Richard P. The Society of the Muslim Brothers. London: Oxford University Press, 1969.

Olson, Robert W. The Emergence of Kurdish Nationalism and the Sheikh Said Rebellion, 1880-1925. Austin: University of Texas Press, 1989.

Olson, Robert W. ; Tucker, William F, “The Sheikh Sait Rebellion in Turkey (1925): A Study in the Consolidation of a Developed Uninstitutionalized Nationalism and the Rise of Incipient (Kurdish) Nationalism", Die Welt des Islams, 1978, Vol.18(3/4), pp.195-211

Özoğlu, Hakan. From Caliphate to Secular State: Power Struggle in the Early Turkish Republic. Santa Barbara, Calif: Praeger, 2011.

Pankhurst, Reza. The Inevitable Caliphate? A History of the Struggle for Global Islamic Union, 1924 to the Present. London: Hurst \& Company, 2013.

Prasad, Bimal. A Nation Within a Nation, 1877-1937. New Delhi: Manohar, 2000.

Qureshi, M. Naeem. Pan-Islam in British Indian Politics: A Study of the Khilafat Movement, 1918-1924. Leiden: Brill, 1999

Rahman, Fazlur, "Muhammad Iqbāl and Atatürk's Reforms", Journal of Near Eastern Studies, 1984, Vol.43 (2), pp.157-162

Robinson, Francis. “Crisis of Authority: Crisis of Islam?", Journal of the Royal Asiatic Society of Great Britain \& Ireland, vol 19, 2009. 
Rustow, Dankwart A, "The Army and the Founding of the Turkish Republic", World Politics, 1959, Vol.11(4), pp.513-552

Sayyid-Marsot, Afaf Lutfi. Egypt's Liberal Experiment, 1922-1936. Berkeley: University of California Press, 1977.

Steinmo, Sven. "Historical Institutionalism" in Approaches and Methodologies in the Social Sciences: A Pluralist Perspective, Eds. Donatella Della Porta and Michael Keating, Cambridge 2008.

Talbot, Ian. India and Pakistan: Inventing the Nation. London: Arnold, 2000.

Tibi, Bassam. The Crisis of Modern Islam: a preindustrial culture in the scientifictechnological age. Salt Lake City: University of Utah Press, 1988.

Toynbee, Arnold. Survey of International Affairs, 1925. Volume 1, part 1 "The Islamic World since the peace settlement", London, Oxford University Press 1927.

Zürcher, Erik Jan. Political Opposition in the Early Turkish Republic: The Progressive Republican Party, 1924-1925. Leiden: E.J. Brill, 1991.

Zürcher, Erik Jan. Turkey: A Modern History. London: I.B. Tauris, 1997. 